\title{
Tropical agroindustrial biowaste revalorization through integrative biorefineries—review part l: coffee and palm oil by-products
}

\author{
Jose-Aníbal Mora-Villalobos ${ }^{1,2}$ • Francisco Aguilar ${ }^{3}$ - Ana-Francis Carballo-Arce ${ }^{2}$. José-Roberto Vega-Baudrit ${ }^{2}$. \\ Humberto Trimino-Vazquez ${ }^{2}$. Luis Roberto Villegas-Peñaranda ${ }^{2}$. Anne Stöbener ${ }^{4}$. Daniela Eixenberger ${ }^{4}$. \\ Paul Bubenheim ${ }^{4} \cdot$ Manuel Sandoval-Barrantes ${ }^{2} \cdot$ Andreas Liese $^{4}$ (I)
}

Received: 12 September 2020 / Revised: 4 March 2021 / Accepted: 9 March 2021 / Published online: 13 April 2021

(C) The Author(s) 2021

\begin{abstract}
Tropical crops are an important source of wealth in many countries. The current agribusiness model is based on the production of a final commodity, leading to the production of organic by-products (biowastes) that in many cases contain bioactive compounds with a potential added value. The exploitation of these by-products is the foundation of the circular economy that leads to the generation of greener bioprocesses for the industry with foreseeable economic improvements in production systems. This review aims to point out the idle opportunities of agricultural production systems and their associated biowastes to contribute to the establishment of a bioeconomy. Hence, the focus lies on five tropical extensive crops: coffee, oil palm, sugar cane, banana, and pineapple. This first part of the review explores agricultural wastes originated from the coffee and oil palm industrial process and is oriented on the potential use of these by-products as a starting material for the alternative obtention of chemicals, otherwise obtained from petrochemistry. The second part of the review focuses on prospective use of lignocellulosic rich biowaste that is derived from the industrialization of sugar cane, banana, and pineapple. A fundamental difference for the use of coffee biomass compared to other crops is the presence of numerous bioactive compounds that are not yet properly utilized, such as antioxidants (i.e., caffeic acid, chlorogenic acid, ferulic acid), as well as their possible use in the manufacture of products of interest in the cosmetic (i.e., quinic acid) or pharmaceutical industry (i.e., caffeic acid phenethyl ester). In the case of oil palm, its potential lies in obtaining chemicals such as glycerol and carotenoids, or in the bioenergy production.
\end{abstract}

Keywords Waste biorefinery $\cdot$ Coffee by-products $\cdot$ Oil palm biorefinery concept $\cdot$ Value-added products $\cdot$ Circular economy Bioeconomy

Manuel Sandoval-Barrantes manuel.sandoval.barrantes@una.cr

$\triangle$ Andreas Liese liese@tuhh.de

1 National Center for Biotechnological Innovations (CENIBiot), National Center for High Technology (CENAT), 1174-1200, San Jose, Costa Rica

2 National University of Costa Rica (UNA), School of Chemistry, 86-3000, Heredia, Costa Rica

3 Leibniz University of Hannover (LUH), Institute of Technical Chemistry, Callinstr. 5, 30167 Hannover, Germany

4 Hamburg University of Technology (TUHH), Institute of Technical Biocatalysis, Denickestr. 15, 21073 Hamburg, Germany

\section{Introduction}

Circular economy is an alternative to the linear economic model, which aims to turn goods at the foreseeable end of their lifecycle into (re)useable materials or resources for other valuable applications [1], with two important consequences: first, the maximization of resources, and second, the minimization of waste production $[2,3]$. Under a circular (bio)economy approach, agroindustrial waste management attends to some of the current agricultural issues from two perspectives: economy and sustainability of the industrialization process.

The biorefinery concept was initially focusing on energy production (i.e., ethanol, hydrogen, butanol) from biomass feedstock; in the recent years, the concept evolved to include the obtention of bulk and fine chemicals as products refined from the raw biomass [4-6]. A biorefinery process for biomass will increase the original feedstock's value to turn the 
original materials into more valuable bio-based products [7]. Hence, regarding the lifecycle of biomass, the biorefinery concept is placed at the intersection of sustainability and circular economy.

Biomass candidates to be utilized in a biorefinery may be limited by the quantity and quality of the available supply [4, 5]. Due to the low cost, high abundance, and high price of potential products, coffee and oil palm biowaste is an excellent source in prospect to develop biorefinery concepts. Coffee and palm oil are two of the most important commodities traded worldwide. In 2018 global coffee production was more than 165 million $60-\mathrm{kg}$ bags of green coffee. This number represents only a small portion of the bulk biomass generated during the production process. The coffee industry generates huge amounts of different kinds of residues such as silverskin, pulp, husks, stems, and wastewater [8-10]. Similarly, the palm oil industry generates over 190 million tons of waste from solid and liquid residues every year, and around $10 \%$ are commercially used for the production of value-added bioproducts [11]. These residues are a source of contamination for water bodies and lands around the plantations, and a serious environmental problem for producing countries.

Costa Rica is a tropical country located in Central America with an enormous biodiversity, and as in other tropical countries there are several species of microorganisms, insects, and plants, among others, still expected to be discovered $[12,13]$. Most of these natural resources are unexplored and bear great potential for the discovery of novel organic compounds as well as biocatalysts for enzymatic synthesis. Due to the variety of temperature, humidity, and rainfall, tropical countries hold different life zones. Costa Rica has 12 life zones, where the most extensive are the tropical wet forest, premontane wet forest, lower montane wet forest, premontane rain forest, and tropical moist forest. Because of this diversity, the country allowed the establishment of different types of crops; thus, agriculture is an important sector within the Costa Rican economy. The country is one of the major banana and pineapple producers worldwide and currently it is considered as a model of environmental sustainability [14].

Costa Rican agriculture covers around 560,000 ha, which represents almost $11 \%$ of the land. The most extensive crops are coffee, oil palm, sugar cane, banana, and pineapple [15]. As shown in Table 1, these crops have an important economic impact. The overall agroindustry produces around 2.5 million tons of agricultural commodities per year, which results in a considerable generation of by-products and wastes, such as coffee pulp, pineapple stubble, oil palm by-products, sugar cane bagasse, and banana stalk that are continuously studied as a potential source of wealth. The abundance of agricultural low-cost biomass has a high potential for developing countries to add value to their agricultural industry, which can be directed to the production of bulk and fine chemicals for international markets.
While agribusiness focuses on the production of the final commodities, the world aims for sustainable systems that mitigate the environmental impacts produced by the agroindustrial sector. This is especially true for developing countries since in most cases agricultural by-products are treated as waste. An integrated alternative to valorize the biomass is through biorefineries, which are facilities that convert biomass to fuels, heat and/or value-added products [17]. Therefore, the use of biorefineries to take advantage of biowastes becomes a way to improve the economic performance of crop-centered production and to add value to by-products of the process. The aim of this review (part I and II) is to evaluate five relevant tropical crops by presenting information about their features, biomass, and by-products, and to consider biorefinery perspectives for the sustainable production of value-added products.

\section{Coffee biowaste revalorization}

Coffee is an important crop for the national economies of countries in the tropical regions of Africa, Asia, Central, and South America $[9,18]$. In Costa Rica, coffee is the most extensive crop with a total of 93,697 ha [15]. The total production of Costa Rican coffee for 2019/2020 was 1.97 million fanegas (traditional measure of dry capacity: approximately $253 \mathrm{~kg}$ per fanega) of coffee berries, resulting in 1.64 million bags of processed coffee (around 498,000 $\mathrm{t}$ of berries and 98,500 t of processed coffee) [19]. The difference between the harvested berries and the final product is normally treated as by-products with low value or as waste $(399,500 \mathrm{t})$.

These raw materials, discarded in the tropical regions where they are produced, are rich in bioactive compounds, such as chlorogenic and hydroxycinnamic acids as well caffeine and flavonoids (which will be further discussed). One great advantage of this type of biowaste is its accumulation in the coffee processing plants in the beginning of the coffee lifecycle, so no collecting strategy is needed. Another advantage from the biorefinery point of view is the industrial amount available, as coffee waste represents up to $50 \%$ of the coffee harvested biomass [9, 20,21], and this highlights the consideration of creating a coffee waste biorefinery. Overall, this is part of the loop that needs to be closed under a circular bioeconomy approach.

\subsection{Biowaste from the coffee industry}

There is much information about the use and management of biomass from spent coffee ground with potential applications for biorefineries such as the production of polyhydroxyalkanoates [22], antioxidants and polyphenols [7, 23, 24], lactic acid [25], and biodiesel, bioethanol, biogas and biofuels [26-28] as well as biopolymers and biocomposites [29] among other. These products might help to close the loop of this biowaste generated by the final consumer, but it also faces the challenge collecting the 
Table 1 Yearly production data of the major crops from Costa Rica in 2019 [16]

\begin{tabular}{llllll}
\hline Crop & Scientific name & Culture land (hectares) & Production (metric t) & $\begin{array}{l}\text { Productivity } \\
\text { (t/ha/year) }\end{array}$ & $\begin{array}{l}\text { Exports } \\
\text { (million USD) }\end{array}$ \\
\hline Coffee & Coffea arabica & 93,697 & 481,521 & 5.14 & (Green bean) 276.2 \\
Oil palm & Elaeis guineensis & 76,720 & $1,081,800$ & 14.10 & (Oil) 95.4 \\
Sugar cane & Saccharum officinarum & 62,630 & $4,421,210$ & 70.59 & (Sugar) 67.1 \\
Banana & Musa sp. & 48,368 & $2,401,474$ & 49.65 & 997.6 \\
Pineapple & Ananas comosus & 40,000 & $3,328,100$ & 83.20 & (Fresh fruit) 962.8 \\
\hline
\end{tabular}

small amounts of spent coffee ground from individuals and food establishments to attain the required amounts of residues for feasible industrial processing. On the other hand, at the beginning of the production chain, coffee biomass wastes are produced in the range of tons per hectare in the farms and normally these are not or minimally treated.

Production of coffee biomass waste is directly related to coffee fruits (also known as cherry or berry) and the agroindustrial methods linked to their processing, resulting in 30 to $50 \%(\mathrm{w} / \mathrm{w})$ of waste [20]. Coffee fruits (Fig. 1) have an outer skin (pericarp or exocarp), which normally changes to yellow and red as the fruit matures and has an internal and fibrous pulp (mesocarp), a viscous mucilage covering the parchment (endocarp) and an internal silverskin covering the coffee bean (endosperm) [30]. The coffee fruit contains mostly two seeds, which are the main product of the coffee industry, and normally it is traded as green coffee, which is the resulting bean after the removal of the skin, pulp, and parchment. The grain contains a thin layer of material, known as silverskin [31]. The chemical composition of the coffee cherry significantly varies from the parts just described, the crop varieties, geographical region, physiological stage of the fruit, and season. Therefore, a proper characterization of the biomass should be assessed before the establishment of a process for the revalorization of coffee by-products.

The separation of the before mentioned elements from the bean can be done either by a wet or dry process. When applying the dry method, the resulting aggregate of pulp, skin, and parchment is called husk, and it is rich in fermentable sugars.
On the other hand, coffee pulp and mucilage are obtained by the wet method. Coffee mucilage is a highly hydrated and thin viscous layer considered the inner mesocarp of the cherry; it represents about $9 \%(\mathrm{w} / \mathrm{w})$ on wet basis of the mature coffee fruit and presents a conventional tissue organization, where cells exhibit thin cell walls, pectic substances, and noncellulosic polysaccharides $[8,31-33]$. The wet method requires up to $4 \mathrm{t}$ of water to produce $1 \mathrm{t}$ of coffee beans and 3 t of by-product $[34,35]$. The wastewater left after the pulping step normally contains a high amount of pollutants, such as organic matter, which is released from the pulp and mucilage [36]. These residues are considered lignocellulosic byproducts [37]. Table 2 shows a compilation of the characterization of the coffee husks, pulp, and silverskin.

Due to the intense use of water, the industry encourages the use of the dry method; however, this method does not produce the same quality of coffee [40-42]. In Costa Rica, most of the coffee is processed following the wet method, and it is still one of the most important processes used worldwide. Accordingly, coffee pulp and mucilage are major byproducts generated by the coffee industry; hence, the design and constant improvement of appropriate methods for the sustainable valorization of these are needed.

\subsection{Bioactive relevant organic compounds from coffee biowaste}

Due to the content of organic matter present in coffee byproducts, there is the possibility to be used as animal feed or
Fig. 1 Coffee fruits. a Coffee fruits on the plant, and $\mathbf{b}$ coffee cherry and green coffee bean anatomy
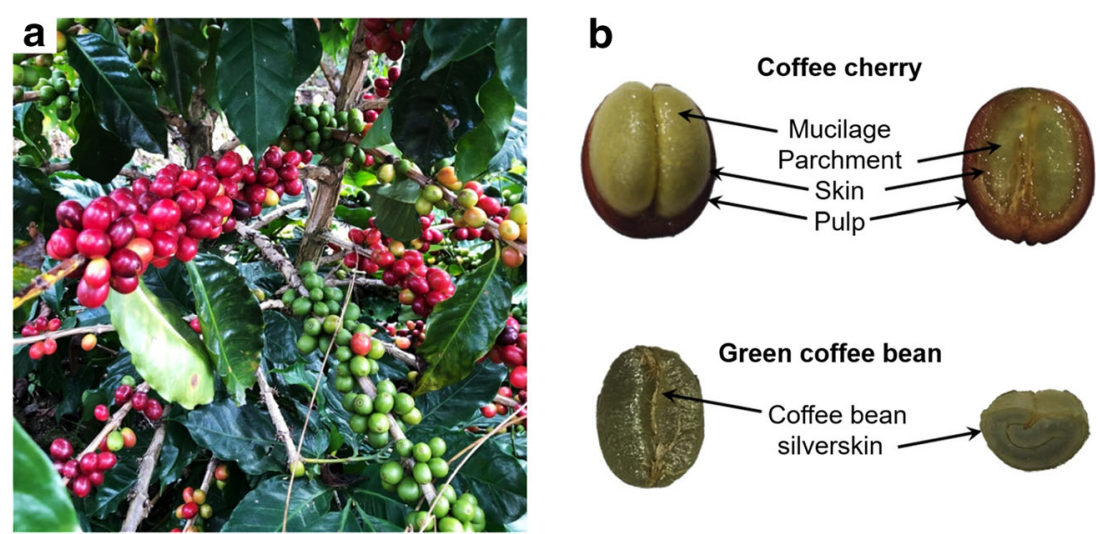
Table 2 Lignocellulosic composition (percent) of coffee by-products (dry weight)

\begin{tabular}{llll}
\hline Contents & Coffee Husk [38] & Coffee Pulp [32, 33] & $\begin{array}{l}\text { Coffee } \\
\text { silverskin [39] }\end{array}$ \\
\hline Cellulose & 26.5 & $12.6-28.6$ & 17.8 \\
Hemicellulose & 25.5 & 17.1 & 13.1 \\
Lignin & 33.5 & 26.0 & \\
Carbohydrate* & & 31.6 & 4.7 \\
Ashes & 0.2 & $8.9-9.1$ & 15.0 \\
Extractives & 6.7 & & 16.2 \\
Protein & & $4.7-8.0$ & \\
\hline
\end{tabular}

* Starch and sugars reported as glucose

* Ethanol soluble compounds

as fertilizers. Nevertheless, undesired effects were reported in chickens when fed with a corn/coffee pulp mix $(50 \% \mathrm{w} / \mathrm{w})$ [43]; and chlorogenic acid has a phytotoxic effect on plants [8, $44,45]$. Organic bioactive compounds such as caffeine, low molecular mass phenols (including chlorogenic acids), and tannins have been associated with these adverse effects; many of these compounds have industrial potential due to their biological activities. The content of bioactive organic compounds in coffee pulp has been reported in several studies; Table 3 compiles the information relating their concentration in the pulp. The chemical formula and structure of these compounds are presented in Fig. 2.

Phenolic compounds in coffee pulp and green coffee beans are classified as anthocyanidins, tannins, hydroxycinnamic acids, and flavonols [47]. Chlorogenic acids are the main hydroxycinnamic acids; they are constituted by a phenolic acid residue esterified with an alcohol group from the quinic acid [7]. These compounds are responsible for astringency and pigmentation properties in the coffee beans. The major classes of chlorogenic acids are caffeoyl-, ferulic-, and dicaffeoylquinic acids (Fig. 2) and their isomers [41, 49]. Hydroxycinnamic acids are mainly linked to the cell walls in coffee pulp by covalent

Table 3 Bioactive organic compounds in coffee pulp

\begin{tabular}{ll}
\hline Compound & $\begin{array}{l}\text { Amount (g/kg in coffee } \\
\text { pulp (dry basis)) }\end{array}$ \\
\hline Total phenols & $20.0[46]$ \\
Polyphenols & $4.55[47]$ \\
Anthocyanins & $0.24[47]$ \\
Polymeric anthocyanins & $0.23[47]$ \\
Hydroxycinnamic acids & \\
Esterified (bound to the cell wall) & $4.4[48]$ \\
Free & $0.86[48]$ \\
Tannins & $7.4[46]$ \\
Caffeine & $18[46]$ \\
\hline
\end{tabular}

bonds. In this sense, it is stated that coffee fruits possess chlorogenic acids linked to the cell walls, as a possible mechanism to protect them from microbial degradation $[48,50,51]$.

\subsubsection{Fine chemicals present in coffee biowaste}

The coffee pulp is composed of high amounts of polyphenols, which can be used as therapeutic compounds due to their biological activity. From these compounds, chlorogenic acids excel among others, due to their hepatoprotective, neuroprotective, antioxidant, anti-inflammatory, anti-obesity, and anticancer activities [52-60].

Chlorogenic acids represent the $42 \%$ of phenolic compounds present in fresh coffee pulp [61]. These can be isolated by simple methods such as water distillation at $80{ }^{\circ} \mathrm{C}$ for $30 \mathrm{~min}$ in the dark, followed by subsequent acidification $(\mathrm{pH}$ 3.0) with phosphoric acid and vacuum filtration. After filtration, chlorogenic acids can be recovered with ethanol. Due to the therapeutic properties of chlorogenic acid, its global market is expected to grow from 132.2 million USD in 2020 up to 154.2 million USD by the end of 2026 (www.wrcbtv. com). The isolation of chlorogenic acids from coffee biomass is a promising approach to produce an important added value from the residues of the coffee industry [62].

Furthermore, chlorogenic acids can be hydrolyzed into caffeic acid and quinic acid. Both compounds have important biological activities. Caffeic acid is a potent antioxidant with anti-inflammatory and antiatherogenic effects [63], and quinic acid has been used to reduce facial wrinkles [64]. Moreover, chlorogenic, quinic, and caffeic acids have shown anti-viral activity against hepatitis B [65].

Chlorogenic acid can be chemically hydrolyzed by an acid catalysis, or enzymatically by the use of microorganisms, i.e., Aspergillus niger $\mathrm{C} 23308$, which converts chlorogenic acids into caffeic acids and quinic acids [66]. Another promising derivative from chlorogenic and caffeic acid is their resulting ester with 2-phenylethanol. The compound is widely known as CAPE: caffeic acid phenethyl ester. CAPE is a potent cytotoxin against melanoma tumor and breast carcinoma cell lines [67]. Furthermore, CAPE inhibited growth and induced apoptosis in colon cancer cell lines [68] and has anti-tumor effects in preclinical models of human breast cancer [69]. The coffee pulp compounds show great potential for the production of fine chemicals. Figure 3 shows a schematic representation of a putative process to recover promising compounds from coffee biomass, relevant to the pharmaceutical and cosmetic industry.

\subsubsection{Bulk chemicals present in coffee biowaste}

The main bulk chemicals from coffee biomass are the lignocellulosic materials: lignin, cellulose, and hemicellulose. Different methods have been used to recover these compounds, and approaches compatible with the industry have already been 
Fig. 2 Mayor organic bioactive compounds present in coffee fruits. a Chlorogenic acid, $\mathbf{b}$ hydroxycinnamic acids (caffeic acid, $\mathrm{R}^{\prime}: \mathrm{OH}, \mathrm{R}^{\prime \prime}: \mathrm{OH}$; ferulic acid, $\mathrm{R}^{1}: \mathrm{H}_{3} \mathrm{CO}, \mathrm{R}^{2}: \mathrm{OH} ; p$-cumaric acid, $\left.\mathrm{R}^{1}: \mathrm{H}, \mathrm{R}^{2}: \mathrm{OH}\right), \mathbf{c}$

representative structure of

flavonoids, and $\mathbf{d}$ caffeine<smiles>O=C(/C=C/c1ccc(O)c(O)c1)O[C@@H]1C[C@@](O)(C(=O)O)C[C@H](O)[C@H]1O</smiles>

b<smiles>[R]c1ccc(/C=C/C(=O)O)cc1[R]</smiles><smiles>O=c1cc(-c2ccc(O)cc2)oc2cc(O)cc(O)c12</smiles>

d<smiles>Cn1c(=O)c2c(ncn2C)n(C)c1=O</smiles>

published, e.g., coffee husk can be treated with $1 \% \mathrm{H}_{2} \mathrm{SO}_{4}$ for $10 \mathrm{~min}$ at $25 \mathrm{rpm}$ and $120^{\circ} \mathrm{C}$ to dissolve hemicellulose. Subsequently, it is possible to remove lignin using $1.5 \%$ $\mathrm{NaOH}$ and applying a soda pulping process $[38,70,71]$.

Besides, the fermentable sugars originated from the pulp or mucilage or obtained by hydrolysis from cellulose and have been used for the production of bioethanol. Coffee pulp and mucilage were used for the production of bioethanol using Saccharomyces cerevisiae and molasses from the sugar cane industry, achieving up to $77 \%$ of fermentative yield [72]. Furthermore, $S$. cerevisiae has been immobilized in alginate beads and employed for the fermentation of mucilage, resulting in a feasible method for continuous ethanol fermentation [73]. A comprehensive biorefinery concept for coffee waste biomass
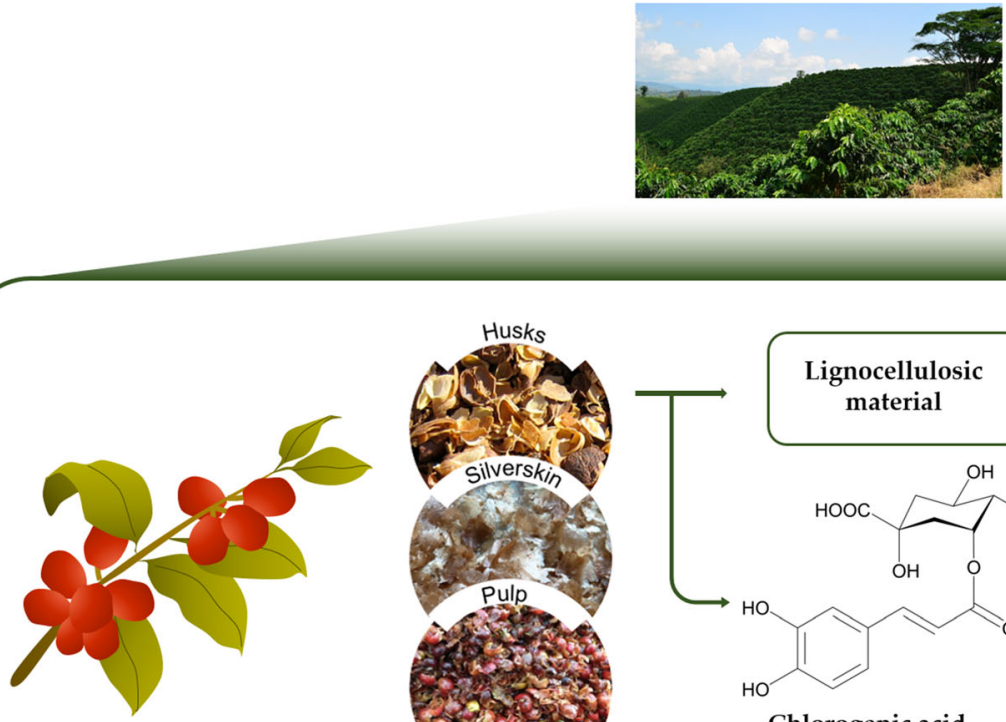

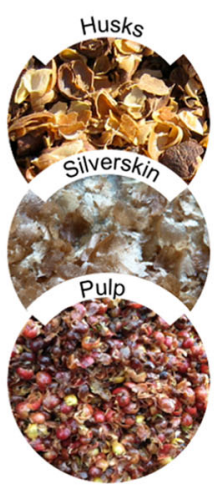

Coffee

biowastes
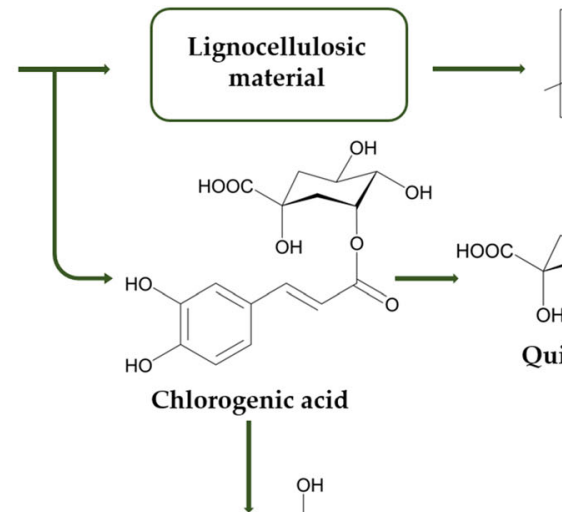

(OH

$\left.\mathrm{O}_{\mathrm{OH}}^{\mathrm{HO}}\right]_{\mathrm{O}}^{\mathrm{O}}$

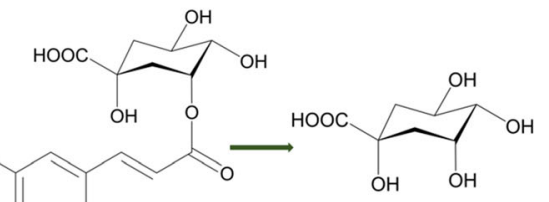

Quinic acid

Chlorogenic acid

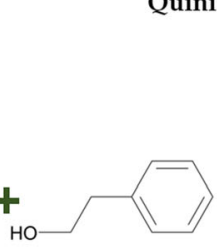

Phenethyl alcohol

Bulk chemicals (fermentable sugars, bio-based materials)

Fine chemicals (cosmetic, nutraceutical, pharmaceutical industries)

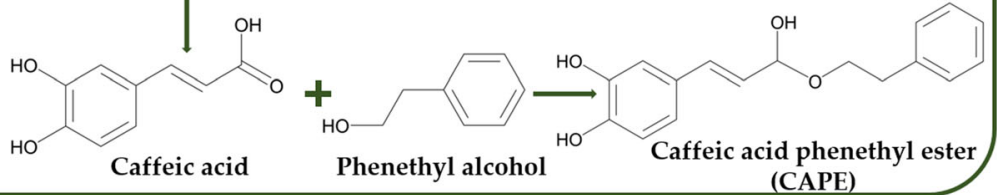

(CAPE)

Fig. 3 Biorefinery approach to coffee biomass management 
comprises different residues and strategies for their isolation, which involves bioactive compounds such as chlorogenic, quinic, and caffeic acids, as well as the management of soluble sugars for bioethanol production and the purification of important bulk chemicals like cellulose pulp (Fig. 3).

Coffee pulp has been investigated as pectin source. The extraction requires ethanol additions to the dry coffee pulp, it produces an alcohol insoluble residue (AIR) which is further placed in a boiling aqueous solution of $0.1 \mathrm{M} \mathrm{HNO}_{3}$ for $30 \mathrm{~min}$ and then the clarified liquid is mixed with absolute ethanol to precipitate the pectin. As result, researchers conclude coffee pulp is a potential source of commercial pectin with gelling properties [74].

\subsection{Biorefinery perspectives for coffee biomass.}

Coffee biowaste in Costa Rica is mainly referred to as coffee pulp, which is a complex mixture of lignocellulosic and bioactive compounds. Thus, the degradation and further application to produce higher value products is a promising opportunity for the country. Coffee biomass management leads to two main potential scenarios. On the one hand, it is possible to detoxify coffee waste biomass with biological pretreatments to use it as soil fertilizer, which is the current case in Costa Rica. Soil fertilizers pose a low-cost alternative to treat a high amount of biowaste; these fertilizers close a loop of nutrients that are taken from the plant and taken back to the fields. Moreover, coffee pulp possesses a high amount of fermentable sugars which can be used to grow a vast list of microorganism that are currently used for biocontrol of plagues and diseases, or for bioremediation. On the other hand, it is possible to obtain value-added products from this biomass, by a biorefinery approach which would significantly reduce the amount of untreated biowaste that can be left in the fields. Other residues from these processes can be transformed into energy, either by anaerobic digestions or by combustion. In the case of coffee, this energy is normally reintroduced to the process in the production stage (Fig. 4).

Biological detoxification with coffee biomass has been done, e.g., Streptomyces exfoliatus 42 and Streptomyces costaricanus 45I-3 have been used to treat coffee pulp, where a reduction of tannin content during the solid fermentation process was reported [75]. Also, caffeine from coffee waste biomass has been removed with Pleurotus jammer, $P$. ostreatus, and P. pulmonarius. However, these microorganisms transferred the caffeine to the mycelia and did not degrade it, so caffeine remained in the fungal biomass [76]. An alternative to detoxify the coffee pulp has been the addition of enzymatic cocktail extracts from Aspergillus tamarii, Rhizomucor pusillus, and Trametes sp. to hydrolyze the chlorogenic and caffeic acids linked to cell walls for further extractions, achieving $36 \%$ and $33 \%$ respectively of enzymatic extraction $[48,66]$.
The current information about coffee pulp management in Costa Rica is highly related to this fungal fermentative approach. Most of the coffee is processed by the wet method; in consequence, the amount of coffee pulp is high. The industry where the coffee pulp is produced (known in Costa Rica as "Beneficio") usually holds the coffee pulp in special facilities (such as open-air concrete tanks, covered with plastics during the rainy season) to avoid its contact with soil or water. There, the coffee pulp starts a natural degradation where microorganisms decompose coffee bioactive compounds (which takes about 2 months); in some cases, this pulp is mixed with poultry manure. This solid-state fermentation process produces characteristic smells; thus, $67 \%$ of the Beneficios add lime (calcium oxide), enzymes, or molasses to decrease these odors. After this solid and spontaneous fermentation process, the resulting byproduct is used as fertilizer in the coffee plantations [77].

\section{Oil palm biowaste revalorization}

The oil palm tree is a relevant oleaginous crop from tropical regions and of economic importance for the production of edible oils and derived chemicals. These monocotyledon palms are classified into the genus Elaeis, which includes two species: E. oleifera originates from Central and South America and E. guineensis is ubiquitous to West Africa (Nigeria) [78, 79]. E. guineensis Jacq. is used mainly for commercial plantations, comprising the varieties Delhi dura, pisiferas and tenera hybrid [80]. E. oleifera is mostly used for the development of hybrids with $E$. guineensis due to its higher content of oleic and linoleic acids [81]. Palm oil production in Costa Rica is based on the growth of E. guineensis or hybrids, like in the rest of the world.

Palm oil is the major product from the oil palm industry and since the mid-2000s, it has displaced soybean oil as the most important edible oil in the world [82]. Worldwide palm oil production has reached over 69 million metric tons (MMT) in 2017 with Indonesia, Malaysia, and Thailand as the major producers [83]. In this same year, Costa Rica produced 0.27 MMT, regardless of its low participation in the international market, at a national level palm oil production is very important given that oil palm is the second most extensive crop in Costa Rica with around 66,500 ha reported in 2016 [15].

Even though, linear economy models are preferred in terms of profitability, the vast amount of biomass generated from oil palm has stimulated the development of biorefineries. The valorization of byproducts using a circular economy approach has a great potential due to the recycling of nutrients back to the fields and the generation of steam and electricity [84]. Nevertheless, there are still many challenges that should be addressed to optimize and integrate a full process in the oil palm industry. These obstacles have been thoroughly described by others [85-89]. 
Fig. 4 A circular economy approach of a coffee-based biorefinery for the revalorization of biowastes towards value-added products. Rectangles indicate process. Curved white rectangles indicate biowastes. Curved greenfilled rectangles indicate valueadded products. Blue dotted line indicates circular economy loops

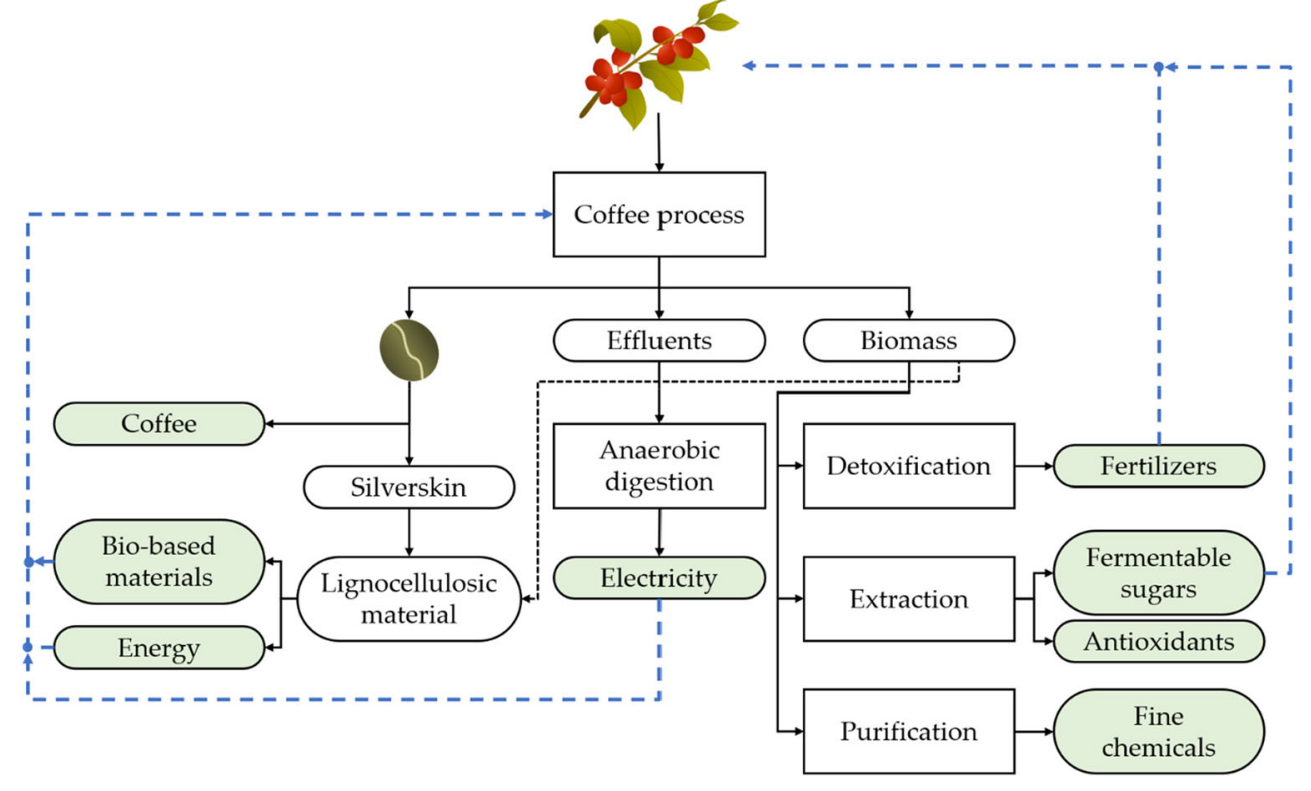

\subsection{Chemical characterization of palm fruit oils}

Two kinds of palm oils are obtained from the palm fruit, which differs greatly in their chemical profile and therefore, in their applications. Crude palm oil (CPO) is extracted from the fruit's mesocarp, showing a balanced mixture of saturated and unsaturated fatty acids and used mainly for the production of foods such as margarine and palm oil. Palm kernel oil (PKO) is obtained from the fruit kernel and is composed mostly of unsaturated fatty acids. Therefore, it is used primarily for oleochemical applications and holds $12 \%$ from palm oil production [90, 91].

The chemical characterization of the CPO and PKO has been extensively studied as reported elsewhere [81, 90, 92, 93]. The main component of the palm oil is triacylglycerols which are esterified glycerol molecules with three fatty acids. They constitute nearly $95 \%$ of the total oil followed by minor components, such as oil-soluble molecules, which are also present in the mesocarp extraction [81].

\subsubsection{Fatty acids}

The composition of fatty acids could oscillate depending on the production region due to geographical factors [94]. Generally, the main fatty acids of CPO are palmitic acid (16:0), oleic acid (18:1), linoleic acid (18:2), stearic acid (18:0), myristic acid (14:0), and lauric acid (12:0) (Table 4). Accordingly, CPO has nearly a 1:1 ratio of saturated and unsaturated fatty acids [102]. The fractioning of CPO, based on crystallization differences, yields palm olein $65-70 \%$ (low melting fraction) and palm stearin 30-35\% (high melting fraction) [90]. As shown in Table 4, the fatty acid profile of palm olein is similar to that of $\mathrm{CPO}$, but with a higher content of unsaturated oleic and linoleic fatty acids. On the contrary, palm stearin is higher in saturated fatty acids with higher levels of palmitic acid. The PKO displays also a saturated fatty acid mixture but differs with a higher content of lauric acid and myristic acid.

\subsubsection{Triglycerols}

The CPO's fractions, palm olein, palm stearin, and super olein, are mainly composed of triglycerols (94-98\%). Additionally, a small fraction is acylglycerols (diglycerols $5-8 \%$ and monoglycerols $0.2-0.3 \%$ ), which are derivatives from the hydrolysis of triacylglycerides (TA) $[90,103]$. The specific composition of fatty acids and triglycerols has been summarized before [90, 92], whereas the TA composition range from $\mathrm{C} 44$ to C56. Disaturated TA comprises $48.8 \%$ followed by $36.5 \%$ monosaturated TA, 9.8\% trisaturated TA, $4.9 \%$ diunsaturated, and $4.8 \%$ triunsaturated $[90,104,105]$.

\subsubsection{Minor constituents}

Minor constituents of $\mathrm{CPO}$ include fatty acid derivatives: monoacylglycerols, diacylglycerols, esters, and free fatty acids. Additionally, the unsaponifiable fraction from CPO comprises more minor constituents such as pigments (carotenoids, lycopene, and xanthophylls), tocopherols, tocotrienols, sterols, phosphatides, and aliphatic/triterpenic alcohols [81].

\subsection{Chemical characterization of palm oil biowaste}

The palm oil processing generates high amounts of biomass waste, which requires special management to prevent environmental issues [106]. Only $10 \%$ of the total oil palm tree is used 


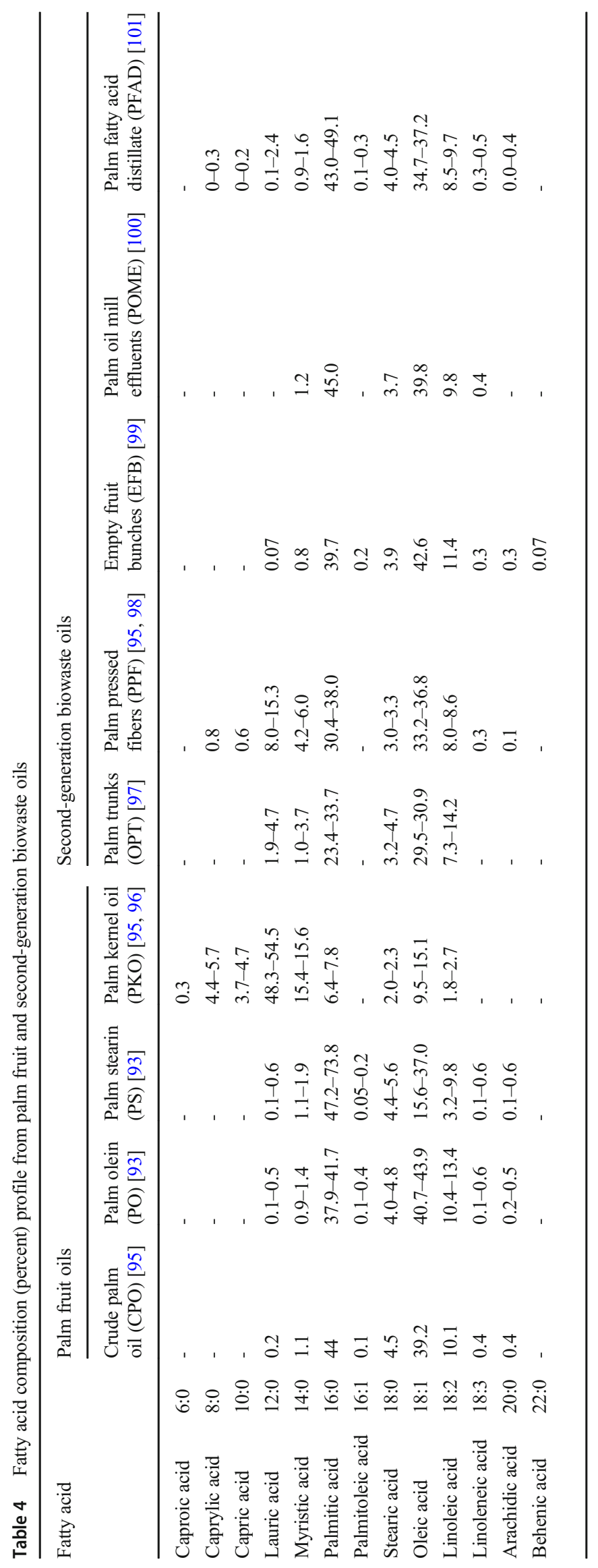


for palm oil production. As a result, oil palm biowastes are estimated at $21.63 \mathrm{t}$ per oil palm hectare [107, 108]. Feedstocks originated from oil palm plantations, are defined as second-generation biowastes, and comprise oil palm trunks (OPT), oil palm roots (OPR), oil palm leaves (OPL), and oil palm fronds (OPF). Moreover, palm oil extraction mills generate most of the biowastes, including empty fruit bunches (EFB), palm kernel shells (PKS), palm pressed fibers (PPF), and palm oil mill effluents (POME) [109, 110]. However, these biowastes hold important potential for the production of bioproducts, such as biofuels and phytochemicals due to their specific chemical composition [108].

\subsubsection{Fatty acids}

The extraction of fresh fruit brushes (FFB) in oil palm mills yields approximately $20 \%$ of palm oil (CPO and PKO) and is performed generally in a one-stage pressing [95]. Thus, the process of biowastes still holds low quantities of oil content due to oil losses. Palm pressed fibers are the biowaste that contains the highest oil content followed by kernel shells and mill effluents (Table 4). Accordingly, the fatty acid composition of the pressed fibers is similar to oil with a balanced saturated/unsaturated fatty acid profile, with oleic (18:1), palmitic (16:0), lauric (12:0) and linoleic acids (18:0) as the major fatty acids (Table 5) [99]. Similarly, mill effluents and palm fatty acid distillate show a comparable fatty acid composition with a high content of palmitic (16:0) and oleic acid (18:1). On the contrary, empty fruit bunches contain more unsaturated fatty acids with a high content of oleic (18:1), palmitic (16:0), and linoleic fatty acids (18:0).

Biowastes from plantations have a low oil content $(2 \% \mathrm{w} / \mathrm{w})$, whereas trunks have a similar fatty acid profile as $\mathrm{PO}$ with oleic (18:1) and palmitic acid (16:0) as major fatty acids. Due to the low oil content of plantation biowastes, oil palm mills generally avoid their re-extraction. Therefore, palm research has focused mainly on the most abundant components of palm biowastes, such as cellulose, hemicelluloses, lignin, and sugars, which could be used for bioenergy and biofuels [109, 119, 120].

\subsubsection{Lignocellulose and sugars}

The oil palm industry produces high amounts of lignocellulosic biomass which is classified into two types: plantation

Table 5 Chemical characterization of second-generation biowastes according to their origin

\begin{tabular}{|c|c|c|c|c|c|c|}
\hline & \multicolumn{2}{|l|}{ Plantation biowastes } & \multicolumn{4}{|c|}{ Palm oil mill biowastes } \\
\hline & Palm trunks (OPT) & $\begin{array}{l}\text { Oil palm } \\
\text { fronds (OPF) }\end{array}$ & $\begin{array}{l}\text { Empty fruit } \\
\text { bunches (EFB) }\end{array}$ & $\begin{array}{l}\text { Palm kernel } \\
\text { shells (PKS) }\end{array}$ & $\begin{array}{l}\text { Palm pressed } \\
\text { fibers (PPF) }\end{array}$ & $\begin{array}{l}\text { Palm oil mill } \\
\text { effluents (POME) }\end{array}$ \\
\hline Oil palm wastes $(\% \mathrm{t} / \text { year })^{\mathrm{a}}$ & 9.90 & 42.76 & 17.37 & 4.33 & 10.65 & 13.8 \\
\hline $\operatorname{Ash}(\mathrm{w} / \mathrm{w} \%)^{\mathrm{b}}$ & $2-4$ & $2-8$ & $1-6$ & $1-2$ & $3-9$ & - \\
\hline Crude protein $(\mathrm{w} / \mathrm{w} \%)^{\mathrm{c}}$ & 2.8 & 4.7 & 3.7 & 17.2 & 5.4 & 12.5 \\
\hline Oil content $(\% \mathrm{~kg} / \mathrm{t} \mathrm{FFB})^{\mathrm{d}}$ & 2 & 2 & 4.5 & $1.2-17$ & $5-6$ & 4.5 \\
\hline \multicolumn{7}{|c|}{ Lignocellulosic content $(\mathrm{w} / \mathrm{w} \%)^{\mathrm{e}}$} \\
\hline Cellulose & 2244 & $40-50$ & $41-46$ & $13-28$ & $39-42$ & - \\
\hline Hemicellulose & $12-41$ & $23-38$ & $25-33$ & $21-22$ & $9-24$ & - \\
\hline Holocellulose & $42-73$ & $70-83$ & $68-86$ & $42-47$ & $49-64$ & - \\
\hline Lignin & $18-36$ & $18-32$ & $27-32$ & $44-52$ & $21-33$ & - \\
\hline Xylose & $15-55$ & $26-52$ & $29-63$ & $63-64$ & $40-49$ & - \\
\hline Glucose & $18-32$ & $20-67$ & $23-66$ & $21-22$ & $23-29$ & - \\
\hline \multicolumn{7}{|l|}{ Element analysis $(\%)^{\mathrm{f}}$} \\
\hline $\mathrm{C}$ & 40.64 & 43.15 & 46.62 & 49.79 & 50.27 & 33.00 \\
\hline $\mathrm{H}$ & 5.09 & 5.64 & 6.45 & 5.58 & 7.07 & - \\
\hline $\mathrm{O}$ & 53.12 & 49.49 & 45.66 & 34.66 & 36.28 & - \\
\hline $\mathrm{N}$ & 2.15 & 1.72 & 1.21 & 0.72 & 0.42 & 26.39 \\
\hline $\mathrm{S}$ & - & - & 0.035 & $<0.08$ & 0.63 & - \\
\hline \multicolumn{7}{|l|}{ Fine chemicals $(\mathrm{ppm})^{\mathrm{g}}$} \\
\hline Sterols & - & - & - & - & $4500-8500$ & - \\
\hline Vitamins & - & - & - & - & $2400-6000$ & - \\
\hline Carotenoids & - & $405-1900$ & 915.25 & 1.6 & $4000-6000$ & $287-1665$ \\
\hline
\end{tabular}

${ }^{\mathrm{a}, \mathrm{e}}[108],{ }^{\mathrm{b}, \mathrm{e}}[111],{ }^{\mathrm{c}}[112],{ }^{\mathrm{d}}[113],{ }^{\mathrm{f}}[106,114-118],{ }^{\mathrm{g}}[95,99,108]$ 
biowaste and oil palm mill biowaste (Table 5). Plantation biowastes contain high amounts of fibers and account for more than $50 \%$ of the total biowastes, comprising fronds and trunks. Both are rich in cellulose (22-50\%) and hemicellulose $(12-41 \%)$ contents as well as lignin (18-36\%) and glucose (18-67\%), respectively [111]. Fronds have high levels of hemicellulose (70-83\%), glucose (20-67\%), and xylose (26$52 \%$ ); hence, it is suitable as a fermentation substrate for the conversion to bioethanol and xylitol [121]. In the case of trunks, $53 \%$ dry weight correspond to fibers and $14-32 \%$ to bark, characterized by high contents of hemicellulose (42$73 \%$ ), which can be processed by pyrolysis for bioenergetic applications [114].

Given the chemical and physical properties of oil palm biomass, several products can be obtained for different industries and applications. Raw fiber can be used as polymers reinterments [122], for sugar conversion [123], for the production of nanocrystals [124], adsorption [125], and for biochar generation by steam pyrolysis [126]. The application is strongly influenced by the type of biomass used and the pretreatments given to the materials.

The biomass from oil palm mills contains similar lignocellulosic matter as plantation biomass, but with higher residual oil content. The largest amount of biowaste from oil palm mills comes from fruit bunches with a ratio of 1.3:1 to CPO [127]. They are characterized by high moisture content $(55 \%$ wet weight) and composed of a stalk with numerous spikelets, which contain 41-46\% cellulose and 25-33\% hemicellulose. Compared to pressed fibers, they have similar cellulose content, but the higher content of xylose (40-49\%) and both can be used for the extraction of nanofibers or pellets for bioenergy $[120,128,129]$. Very different from the aftermentioned biowastes is the kernel shells, consisting of high amounts of xylose (63\%) and lignin (44-52\%). PKS are the remaining shells from the kernels after the crushing stage in which the PKO is further extracted. These are characterized by low moisture $(6 \%)$ and high calorific value and therefore, used as fuel for bioenergy in oil palm mills [130].

\subsubsection{Carotenoids}

The unsaturated tetraterpene carotenoids are present in most vegetable oils and are responsible for the yellow-orange color in edible oils. Carotenoids are present in moderate amounts in oil palm fresh fruits and, after processing, PPF contains nearly $4000-6000$ ppm of carotenoid levels. Nearly $50 \%$ of these correspond to $\alpha$ - and $\beta$-carotenes, followed by lycopene, phytoene, $\zeta$-carotene, and $\delta$-carotene [95]. Lower carotene amounts are found in OPF and POME, ranging between 287 and $1900 \mathrm{ppm}$, and in trace amounts in PKS [108]. The recovered carotenoids have the potential to be used as supplement food nutrients and medicinal applications.

\subsection{Oil palm industry revalorization}

The oil palm industry generates a huge amount of biomass, as an example, worldwide production of oil in 2019/20 was 72.27 MMT, which generated over 200 MMT of waste from solid and liquid wastes. It is estimated that in Costa Rica, 0.52 MMT of waste was produced in that same year. As oil palm biomass is a readily available lignocellulosic biomass, it has the potential to be a low-cost feedstock for conversion into higher value products [131]. Only about $10 \%$ is used to increase the value of the production chain by adding products with high value or by exploiting biomass to produce energy. Biodiesel is one of these valuable products that may be adopted by the oil palm industry. In the late years, demand for biodiesel has increased. Since the combustion of fossilbased fuel has become a concern due to carbon emissions and its relationship with global climate, biodiesel emerges is a notable alternative [121]. On the other hand, agricultural or industrial wastes can be revalorized by converting them to energy; the conversion of biomass to renewable energy requires the breakdown of the main organic components. As mentioned before, these organic compounds range from their complexity and functional groups, which ultimately influence the structure and chemistry of the biomass. This knowledge is important to develop biological and chemical processes that add value to the biomass [128]. Hereon, we describe different applications that can be adopted by the oil palm industry using a circular economy approach to increase the value of their products and biowaste.

\subsubsection{Bioenergy}

The ability to convert biowastes into energy and to incorporate it into the industrial process is a key point for integrated bioeconomy solutions. The development of sustainable processes that harvest, collect, store, and transform biowaste efficiently into energy is generally the determinant to establish the feasibility of the process. Biomass logistics is defined as the flow of material from the production site (e.g., agricultural field) to the point designated to the processing plant for material transformation [110]. In Costa Rica, major palm oil producers are located in the central- and south-pacific region of the country, and so far, all transformation processes were always included within the production facilities.

Different schemes of biomass valorization have been conceived within the oil palm industry in Costa Rica. Biological conversions can transform biomass into renewable energy products; these involve biochemical reactions that degrade biowaste into sugars, starch, and cellulose, and further conversion into bioethanol or biobutanol through a series of biochemical reactions, or the transformation of these products to methane or hydrogen through anaerobic digestion [121]. So far, not much work has been done in this direction in Costa 
Rica, besides the academic-industry research projects which currently are in the state of "proof of the concept" [132, 133].

Biomass can also be converted to energy using different kinds of thermochemical processes. The end-user requirements in terms of power and heat influence the applied process, as well as the biomass source and its nature. Different thermochemical processes can be used to produce energy from biowaste: (1) combustion for the production of steam and power; (2) gasification for the production of gas, which is then used for power/heat generation; and (3) pyrolysis, which produces a liquid that can be used for transportation fuel [109].

In Costa Rica, palm oil mills meet their electricity and steam requirements partially by burning biomass. Combustion is usually carried out in a furnace or a stove, where the fuel is burned directly to produce heat. The industry does not use all the wastes described in Table 5. Usually, palm kernel shells and the palm press fibers are used to produce energy. The main goal of a combustion process is to release the energy stored in the biomass while minimizing losses due to incomplete combustion. It requires an ignition of the biomass; therefore, low moisture is one of the key characteristics required for an efficient process. Hence, palm kernel shells are preferred over another biowaste such as the trunk and fronds, which are normally not used to produce energy. According to Sulaiman et al. (2011) for each kilogram of palm oil, roughly another $4 \mathrm{~kg}$ of dry biomass are produced, which are derived from FFB and organic material. Only a small fraction is used within revalorization process for mulching and as fertilizer, the rest is left in the fields. For each kilogram of palm oil, electricity consumption is around $0.1 \mathrm{kWh}$ and $2.5 \mathrm{~kg}$ of steam, this is met by burning around $0.4 \mathrm{~kg}$ of palm kernel shell [105]. Therefore, little effort has been invested into optimizing the process or including other wastes. Furthermore, the extension of electric production is a major element of the economic viability and is entangled with tariffs and norms that regulate the cogeneration of electrical energy.

Gasification and pyrolysis are two kinds of technologies used to generate power from biomass. The gasification process converts the solid biomass to a gaseous fuel that may later be used for the power/heat generation, transportation, or chemicals. Oil palm residues have around double of volatile matter, between 70 and $90 \%$ (w/w), when compared to coal. This is ideal for gasification since it produces high volumes of gas and lower amounts of char upon heating. Nevertheless, disadvantages such as a low energy density and complexity of the system when compared to a stove limit its applications within the palm oil industry. On the other hand, pyrolysis converts biomass into liquids, solids, and a gaseous fraction by heat (with or without the aid of a catalyst) in the absence of air or oxygen. The liquid fraction can be used as a biofuel for transportation or a source for chemical feedstock. To our knowledge, so far, gasification and pyrolysis have not been used for the production of energy in Costa Rica, although these processes offer many technological advantages [134].

\subsubsection{Biodiesel}

Energy consumption is growing more rapidly than population growth. Sustainable and consistent energy supplies are primordial for any economy [135]. Gasoline and diesel are two of the most important fuels used worldwide. The latter one is largely applied for energy demanding sectors (i.e., transportation, agriculture, and industry) for the generation of power/mechanical energy. It is mainly supplied by petrochemical sources, which brings along problems associated with pollution and the limited quantity of petroleum. This has stimulated the interest in alternatives, and biodiesel fulfills the technical requirements needed to substitute or complement the petrochemical industry: biodiesel production is technically feasible at a large scale, it is competitive and environmentally acceptable [136, 137].

Biodiesel is defined as mono-alkyl esters derived from renewable feedstocks. There is a great structural similarity between biodiesel and diesel derived from petroleum. Like conventional diesel, biodiesel can be produced from vegetable oils, animal fat, and used cooking oils and obtained by transesterification with alcohol. It is a non-toxic and biodegradable fuel that does not contain sulfur, aromatic hydrocarbons, metals, or any crude oil residue. Also, when compared with conventional diesel, biodiesel reduces the emission of $\mathrm{CO}_{2}$ by $78 \%$; this is due to biofuel closes the carbon cycle [121].

Sustainability of the production process depends on several factors: the source of the feedstock (edible crops, wasted oils, others), the pretreatment method of the feedstock, the amount of free fatty acids, type of catalysis employed during the production process, type of alcohol used, and the source of energy used during the process [137]. Out of this, the type of feedstock represents around 75-90\% of the total production costs; therefore, special attention should be paid to the input resources. Thence, palm oil represents a comparatively suitable source of feedstock for biodiesel production since it fulfills several criteria such as high productivity, efficiency, and competitive prices.

In Costa Rica, few companies have integrated a whole process to produce of biofuel and several businesses have emerged in the last years: Central Biodiesel HTP, Biodiesel H\&M, Energías Biodegradables, Dieselloverde Derivel, and Cia Coto 54. Some of these are currently not dedicated to the production of biodiesel [138]. A common factor that limits their production is access to the feedstock at an affordable price. Also, Costa Rica has a National Biofuel Plan in which the Costa Rican Petroleum Refinery (Refinadora Costarricense de Petróleo-RECOPE) strives for a mass production and commercialization of blended biofuels, but, for now, it has been limited to an experimental production [139].

\subsubsection{Bio-glycerol}

Crude glycerol is the major by-product of palm oil biodiesel production, representing $10 \%$ of the products from the 
biodiesel process [140]. A glycerol biorefinery is more likely to be seen as a promoter for a circular economy, where glycerol becomes an attractive, cheap, and local resource and interindustry sharing of resources becomes an integrated part of modern and green business models [141]. As a result, palm oil biorefineries, especially in Malaysia and Indonesia, generate high amounts of crude glycerol, which endanger the environment, if not managed properly. However, there is a high demand for crude glycerol; its world production for 2020 is estimated at 4.0 billion liters [142]. There is an enormous potential for the usage of crude glycerol in high-value products within the food, oleochemical, and cosmetic industry.

Depending on the source of palm oil and the production process, the recovered crude glycerol contains impurities, which affects the purification costs greatly [143]. Herein, we summarize the main production and purification methods according to the palm oil sources.

The traditional method for the production of crude glycerol is the chemically catalyzed transesterification, due to its low cost. The reaction is characterized by the transesterification of triglycerides from PO with an alcohol (usually methanol), in presence of a catalyst (e.g., acid, base), generating fatty acid methyl esters (FAME), and crude glycerol as side product $[144,145]$. Generally, the transesterification reaction yields approximately $90 \%$ biodiesel, 9-9.6\% crude glycerol, and $0.4-1 \%$ of impurities [146].

After transesterification, crude glycerol is separated from biodiesel by centrifugation or decantation, whereas the impurities remain mostly in the crude glycerol. These impurities comprise catalysts, soaps, alcohols, metals, salts, and acylglycerides [147]. Removal of impurities can be performed by different strategies depending on the catalyst used. When a homogeneous catalyst is used, a neutralization stage is performed, whether with an acid $\left(\mathrm{H}_{2} \mathrm{SO}_{4}\right)$ or a base $(\mathrm{NaOH})$. This generates inorganic salts (e.g., fatty acid salts), which are removed by decantation/filtration [146]. With heterogeneous catalysts, the soaps are converted to salts and fatty acids by an acid treatment. Further distillation removes the alcohol and water impurities. Afterward, the mixture is neutralized with a base (e.g., caustic soda) and the salts are removed by filtration, resulting in an $80 \%$ crude glycerol $[146,148]$.

Production of crude glycerol from PKO is performed with homogeneous alkaline catalysts $(\mathrm{NaOH})$, which are removed by an acid wash with $\mathrm{HCl}$. After splitting the soaps, the mixture is neutralized with $\mathrm{NaOH}$, and salts are filtered and further evaporated, yielding crude glycerol $[149,150]$. Similarly, production from $\mathrm{CPO}$ is also performed by the industry with homogeneous catalysts $(\mathrm{NaOH})$. However, Isahak et al. (2010) demonstrated a process with heterogeneous catalysts ( $\mathrm{KOH}$ and $\mathrm{Al}_{2} \mathrm{O}_{3}$ ). After removal of the catalyst by filtration, the mixture was distilled to remove methanol. Crude glycerol was then recovered after neutralization with $85 \%$ phosphoric acid and microfiltration for salt removal.
The recovered crude glycerol from the distinct production process requires further purification to eliminate residual contaminants such as alcohol (e.g., methanol), soaps, and salts. The most common method is vacuum distillation, which can eliminate methanol. The process operates at $120-126^{\circ} \mathrm{C}$ and high purity can be achieved at low costs. Eventually, vacuum distillation can generate side products, if not well performed, including oxidation, polymerization, and dehydration [146].

During the crude glycerol production, a small fraction of catalysts is present as free ions. For their removal, adsorption by ionic exchange resins is a successful method. The use of two resins for binding free anions and cations is a promising strategy, thus hydrogen and hydroxyl ions are exchanged, yielding water. As an example, Isahak et al. (2010) used Amberlite $200^{\circ} \mathrm{C}$ and IRN-78 resins to recover glycerol from glycerol residue from distillation [148]. As for the commercial pure glycerol, the number of free acids was less than 0.08 $0.1 \%$. Purified glycerol from palm oil is processed until commercial or pure grade and used for the production of bulk chemicals, food supplements, additives, cosmetics, and medicaments. Alternatively, it is used for the production of solvents, surfactants, and polymers [151]. These derivatives can be produced via different pathways, which include dehydration, condensation, transesterification, hydrogenolysis, esterification, oxidation, and halogenation, among others.

\subsection{Biorefinery perspective for the oil palm industry focusing on Costa Rica}

Biorefinery is a pilar of circular economy, closing biomass loops instead of treating by-products as waste is a great milestone in the oil palm industry. Biomass can be transformed into usable biofuels and bio-chemicals. Heat, power, and fuels can be easily incorporated into the milling process of the oil.

Biomass can be transformed into usable biofuels and biochemicals applying biorefineries, which are facilities that integrate biomass conversion processes to produce fuels, power, and chemicals. Biodiesel production is a conversion technology used to produce energy. Accordingly, palm oil is transformed into biodiesel based on a catalytic transesterification. This reaction consists of vegetable oil and alcohol (often methanol or ethanol) as substrates to yield fatty acid alkyl esters (i.e., biodiesel) and glycerol. This chemical process is highly influenced by the alcohol to oil molar ratio, the chosen catalyst, temperature, water content, and free fatty acids [152]. Normally, alkali or acid catalysts are used to accelerate the transesterification reaction; therefore, sulfuric acid, sulfonic acid, and hydrochloric acid are often applied as acid catalysts, whereas $\mathrm{NaOH}, \mathrm{KOH}$, carbonates, and alkoxide salts such as sodium or potassium methoxide, ethoxide, propoxide, and butoxide are common examples for alkali catalysts [153]. The latter is most used in industrial processes due to the fast reaction rates at moderate reaction conditions, regardless of 
Fig. 5 The concept for an oil palm-based biorefinery for the revalorization of biowastes towards value-added products. Rectangles indicate process. Curved white rectangles indicate biowastes. Curved green-filled rectangles indicate value-added products. Blue dotted line indicates circular economy loops

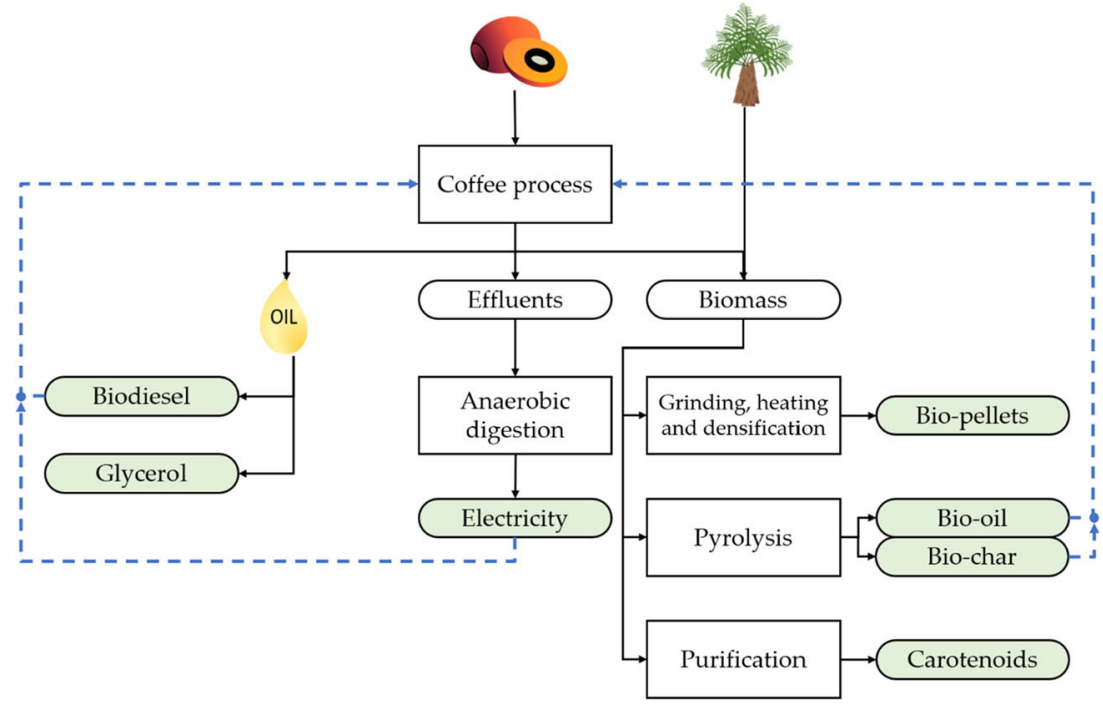

inconveniences such as saponification reactions due to water and free fatty acids. To our knowledge, there are no commercial processes that include acid catalysts in commercial biodiesel plants $[154,155]$.

The removal of catalysts adds costs to the final product due to the energy required for this step. A considerable amount of work has been done recently on the utilization of heterogeneous catalysts. Generally, solid base and acid catalysts are similar to their homogeneous counterparts, both with advantages and disadvantages, being the high cost the major constraint most of the time [156-158]. The transesterification reaction also occurs under catalytic-free conditions with methanol under supercritical conditions, which leads to higher energy consumption and production costs. The main barrier for the commercialization of biodiesel is the cost of production; nevertheless, the continuous increase of the crude oil demand makes biodiesel very competitive when produced under industrial standardized conditions $[152,159]$.

Oil palm biowastes such as fronds, empty fruit bunches, pressed fibers, and kernel shells are suitable for bioenergetical applications due to their high lignocellulosic content. Biopellets are one of the most promising options for revalorization of these biowastes, with applications in power plants to generate energy or furnaces for heating buildings. This biomass possesses a low density and high moisture; thus, its processing requires grinding, heating, and densification [128]. Similarly, biochar and bio-oil produced from pyrolysis is an alternative option for biomass revalorization. The biomass is treated at high temperatures $\left(>500{ }^{\circ} \mathrm{C}\right)$ without oxygen and additionally generates gasses, which can be used to power the pyrolysis plant. Biochar is the solid residue from the reaction and is applied to produce charcoal and chemicals [160]. In the case of Costa Rica, bio-pellets, biochar, and bio-oil were already produced by coffee and pineapple wastes, thus this technology is already established and can successfully be transferred to the case of lignocellulosic oil palm biowastes [161].

The extraction of CPO generates liquids biowastes (mill effluents), which is a major environmental issue in palm oil mills and requires special management. A common treatment is an anaerobic digestion, which is possible due to the high organic content of POME. This process involves distinct reactions such as hydrogenesis, acidogenesis/acetogenesis, and methanogenesis; resulting in water, carbon dioxide, and methane [162]. Anaerobic digestion in closed bio-digestors enables the production and storage of methane, which is a value-added good that is currently used for bioenergy in the industrial sector. Although this process is not common in Costa Rica, different agroindustries adopt such technologies and eventually, those can be applied for POME [163].

Another promising biowaste generated in palm oil mills is PPF because of its content of carotenoids. The latter is involved in the coloration of the fresh fruit and small amounts are still found in the PPF after the pressing stage. The most abundant carotenoids in PPF correspond to $\alpha$-carotenoids, $\beta$-carotenoids, and lycopene $[93,95]$. The extraction of carotenoids from mesocarp from the palm Bactris gasipaes (Arecaceae) was investigated in Costa Rica [164]. Consequently, the application of the extraction methods can be applied to the case of PPF (Fig. 5.).

\section{Conclusions}

Circular economy fosters a shift from linear agricultural models to circular models. Worldwide, the agro industry represents a dynamic sector of the economy; this is true as well for Costa Rica. This sector generates significant quantities of biomass with high potential for the generation of value-added products such as bulk and fine chemicals. Moreover, many of 
the biomass can be transformed or reused within the production process.

Biowastes from the coffee industry, such as pulp and mucilage, currently represent a high cost due to the labors involved in the treatment of the biomass, physical space, and infrastructure. The generation of derived products such as coffee-based fertilizers after processing takes about 2 months. The refinement of coffee biomass to obtain products, such as chlorogenic acid, caffeic acid, and quinic acid from agroindustrial byproducts for cosmetic, nutraceutical or pharmaceutical uses, is an alternative that can generate higher value-added products and improve the economic performance of the sector. Nevertheless, it requires the development of engineering operations in industrial bioprocesses. Biorefinery processes are not a one-fit-all solutions; every case must be considered individually, and case-specific adjustment must be done. In the case of the palm oil industry, it seems to have great potential to produce bioenergy and biofuels, yet it is influenced by policies that affect multiple sectors such as agriculture, research, industry, and trade. Identifying relevant policies and quantifying their specific impacts is difficult given the variety of policy instruments (taxes, subsidies, prices, support, facilities, etc.) and the way they are applied.

Agricultural industry stresses the need to produce within a socially favorable frame and with a distributional effect among all involving parties of the production chain. In this sense, a circular economy approach entails positive effects on employment, food security, environmental conservation, technological advancements, and the benefit to future generations. Although these aspects are normally not considered when assessing the sustainability of an industry, they should always be taken into consideration when analyzing the overall effect within the society. As discussed above, waste revalorization has a positive impact among the latter mentioned factors, therefore its discussion and implementation should be promoted at different levels, i.e., academia, politics, and industry.

Acknowledgements The authors thank the financial support of the German-Costa Rican binational funds from the Bundesministerium für Bildung und Forschung, Germany (CRIWTZ-060 - AgroBioCat), the Ministerio de Ciencia, Tecnología y Telecomunicaciones, and the Consejo Nacional de Investigaciones Cientificas y Tecnológicas, Costa Rica (FI-260B-17).

Author contribution $\mathrm{AL}$ and MS conceived the original idea and funding application, and J-AM-V wrote the manuscript with help of FA, A-FC-A, J-RV-B, HT-V, LV-P, AS, DE, and PB. All authors provided critical feedback and contributed to the final manuscript.

Funding Open Access funding enabled and organized by Projekt DEAL. BMBF (Bundesministerium für Bildung und Forschung, Germany): CRIWTZ-060 (AgroBioCat), Ministerio de Ciencia, Tecnología y Telecomunicaciones and the Consejo Nacional de Investigaciones Científicas y Tecnológicas (CONICIT), Costa Rica (FI-260B-17; Project UNA-SIA-250-18).
Data Availability Not applicable

Code availability Not applicable

\section{Declarations}

Competing interests The authors declare no competing interests.

Open Access This article is licensed under a Creative Commons Attribution 4.0 International License, which permits use, sharing, adaptation, distribution and reproduction in any medium or format, as long as you give appropriate credit to the original author(s) and the source, provide a link to the Creative Commons licence, and indicate if changes were made. The images or other third party material in this article are included in the article's Creative Commons licence, unless indicated otherwise in a credit line to the material. If material is not included in the article's Creative Commons licence and your intended use is not permitted by statutory regulation or exceeds the permitted use, you will need to obtain permission directly from the copyright holder. To view a copy of this licence, visit http://creativecommons.org/licenses/by/4.0/.

\section{References}

1. Stahel WR (2016) The circular economy. Nature 531:435-438

2. Sherwood J (2020) The significance of biomass in a circular economy. Bioresour Technol 300:122755

3. Clark JH, Farmer TJ, Herrero-Davila L, Sherwood J (2016) Circular economy design considerations for research and process development in the chemical sciences. Green Chem 18:3914 3934

4. Ubando AT, Felix CB, Chen WH (2020) Biorefineries in circular bioeconomy: a comprehensive review. Bioresour Technol 299: 122585

5. Cardoen D, Joshi P, Diels L, Sarma PM, Pant D (2015) Agriculture biomass in India: part 1. Estimation and characterization. Resour Conserv Recycl 102:39-48. https://doi.org/10.1016/ j.resconrec.2015.06.003

6. Cherubini F (2010) The biorefinery concept: using biomass instead of oil for producing energy and chemicals. Energy Convers Manag 51:1412-1421. https://doi.org/10.1016/j. enconman.2010.01.015

7. Adwitiya D, Venkatachalapathy N (2016) Profitable exploitation of coffee pulp- a review. Int J Appl Nat Sci 5:75-82

8. Echeverria MC, Nuti M (2017) Valorisation of the residues of coffee agro-industry: perspectives and limitations. Open Waste Manag J 10:13-22. https://doi.org/10.2174/ 1876400201710010013

9. Blinová L, Sirotiak M, Bartošová A, Soldán M (2017) Review: utilization of waste from coffee production. Fac Mater Sci Technol Slovak Univ Technol 25:91-101. https://doi.org/10. 1515/rput-2017-0011

10. Alves RC, Rodrigues F, Antónia Nunes M, et al (2017) State of the art in coffee processing by-products. In: Handbook of coffee processing by-products: sustainable applications. Elsevier Inc., pp 126

11. Lee KT, Ofori-Boateng C (2013) Oil palm biomass as feedstock for biofuel production. Green Energy Technol 138:77-106. https://doi.org/10.1007/978-981-4451-70-3_3

12. Jiménez A, Monroe MC, Zamora N, Benayas J (2017) Trends in environmental education for biodiversity conservation in Costa 
Rica. Environ Dev Sustain 19:221-238. https://doi.org/10.1007/ s10668-015-9734-y

13. Mendenhall CD, Shields-Estrada A, Krishnaswami AJ, Daily GC (2016) Quantifying and sustaining biodiversity in tropical agricultural landscapes. Proc Natl Acad Sci U S A 113:14544-14551. https://doi.org/10.1073/pnas.1604981113

14. Jadin I, Meyfroidt P, Lambin EF (2016) International trade, and land use intensification and spatial reorganization explain Costa Rica's forest transition. Environ Res Lett 11:035005. https://doi. org/10.1088/1748-9326/11/3/035005

15. Ministerio de Agricultura y Ganadería de la República de Costa Rica. (2016) Cultivo de Cafe. Resultados del IV Censo nacional agropecuario

16. Secretaría Ejecutiva de Planificación Agropecuaria (2020) Boletín Estadístico Agropecuario. In: SEPSA \#30. http://www.sepsa.go. cr/productos.html. Accessed 16 Jan 2021

17. Bajpai P (2013) Recycling and deinking of recovered paper. Elsevier Inc

18. Davis AP, Gole TW, Baena S, Moat J (2012) The impact of climate change on indigenous Arabica coffee (Coffea arabica): predicting future trends and identifying priorities. PLoS One 7: e47981. https://doi.org/10.1371/journal.pone.0047981

19. ICAFE, Instituto del Café de Costa Rica (2020) Informe de actividad cafetalera de Costa Rica. San José, Costa Rica

20. Oliveira LS, Franca AS (2015) An overview of the potential uses for coffee husks. Coffee Heal Dis Prev:283-291. https://doi.org/ 10.1016/B978-0-12-409517-5.00031-0

21. Coto Chinchilla O (2013) Evaluación de la Generación de Residuos Agrícolas Orgánicos (RAO) en Costa Rica e Identificación de Sector Prioritario. San José, Costa Rica

22. Obruca S, Benesova P, Kucera D, Petrik S, Marova I (2015) Biotechnological conversion of spent coffee grounds into polyhydroxyalkanoates and carotenoids. New Biotechnol 32: 569-574. https://doi.org/10.1016/J.NBT.2015.02.008

23. Zuorro A, Lavecchia R (2012) Spent coffee grounds as a valuable source of phenolic compounds and bioenergy. J Clean Prod 34: 49-56. https://doi.org/10.1016/j.jclepro.2011.12.003

24. Panusa A, Zuorro A, Lavecchia R, Marrosu G, Petrucci R (2013) Recovery of natural antioxidants from spent coffee grounds. J Agric Food Chem 61:4162-4168. https://doi.org/10.1021/ jf4005719

25. Hudeckova H, Neureiter M, Obruca S, Frühauf S, Marova I (2018) Biotechnological conversion of spent coffee grounds into lactic acid. Lett Appl Microbiol 66:306-312. https://doi.org/10. 1111/lam.12849

26. Rocha MVP, de Matos LJBL, de Lima LP et al (2014) Ultrasound-assisted production of biodiesel and ethanol from spent coffee grounds. Bioresour Technol 167:343-348. https:// doi.org/10.1016/j.biortech.2014.06.032

27. Atabani AE, Al-Muhtaseb AH, Kumar G et al (2019) Valorization of spent coffee grounds into biofuels and value-added products: pathway towards integrated bio-refinery. Fuel 254:115640. https://doi.org/10.1016/j.fuel.2019.115640

28. Kim J, Kim H, Baek G, Lee C (2017) Anaerobic co-digestion of spent coffee grounds with different waste feedstocks for biogas production. Waste Manag 60:322-328. https://doi.org/10.1016/j. wasman.2016.10.015

29. Karmee SK (2018) A spent coffee grounds based biorefinery for the production of biofuels, biopolymers, antioxidants and biocomposites. Waste Manag 72:240-254

30. Farah A, Dos Santos TF (2015) The coffee plant and beans: an introduction. In: Coffee in health and disease prevention. Academic Press, pp 5-10

31. Esquivel P, Jiménez VM (2012) Functional properties of coffee and coffee by-products. Food Res Int 46:488-495. https://doi.org/ 10.1016/J.FOODRES.2011.05.028
32. Ijanu EM, Kamaruddin MA, Norashiddin FA (2020) Coffee processing wastewater treatment: a critical review on current treatment technologies with a proposed alternative. Appl Water Sci 10: https://doi.org/10.1007/s13201-019-1091-9

33. Avallone S, Guiraud J-P, Guyot B, Olguin E, Brillouet JM (2000) Polysaccharide constituents of coffee-bean mucilage. J Food Sci 65: 1308-1311. https://doi.org/10.1111/j.1365-2621.2000.tb10602.x

34. Rigueira RJ de A, Filho AF de L, Matos AT de, et al (2008) Revista engenharia na agricultura. Departamento de Engenharia Agrícola, Universidade Federal de Viçosa

35. Delgado EA, Barois I (1999) Lombricompostaje de la pulpa de café em México. In: Seminario Internacional sobre biotecnología de la agroindustria cafetalera. p p.335-343

36. Rattan S, Parande AK, Nagaraju VD, Ghiwari GK (2015) A comprehensive review on utilization of wastewater from coffee processing. Environ Sci Pollut Res 22:6461-6472. https://doi.org/10. 1007/s11356-015-4079-5

37. Murthy PS, Naidu MM (2012) Production and application of xylanase from Penicillium sp. utilizing coffee by-products. Food Bioprocess Technol 5:657-664. https://doi.org/10.1007/s11947010-0331-7

38. de Carvalho Oliveira F, Srinivas K, Helms GL et al (2018) Characterization of coffee (Coffea arabica) husk lignin and degradation products obtained after oxygen and alkali addition. Bioresour Technol 257:172-180. https://doi.org/10.1016/J. BIORTECH.2018.01.041

39. Carneiro LM, Silva JPA, Mussatto SI, Roberto IC, Teixeira JA (2009) Determination of total carbohydrates content in coffee industry residues. In: 8th International Meeting of the Portuguese Carbohydrate Group, GLUPOR. Cited by Mussato et al. 2011. p 94

40. Kleinwächter M, Bytof G, Selmar D (2015) Coffee beans and processing. Coffee Heal Dis Prev 73-81. https://doi.org/10.1016/ B978-0-12-409517-5.00009-7

41. Duarte GS, Pereira AA, Farah A (2010) Chlorogenic acids and other relevant compounds in Brazilian coffees processed by semidry and wet post-harvesting methods. Food Chem 118:851-855. https://doi.org/10.1016/J.FOODCHEM.2009.05.042

42. Lee LW, Cheong MW, Curran P, Yu B, Liu SQ (2015) Coffee fermentation and flavor - an intricate and delicate relationship. Food Chem 185:182-191. https://doi.org/10.1016/J. FOODCHEM.2015.03.124

43. Braham E (1979) Coffee Pulp in Other Species. In: Braham JE (José E, Bressani R (eds) Coffee pulp. Composition, technology and utilization. International Development Research Centre, pp 51-54

44. Al-Charchafchi F, Al-Quadan F (2010) Effect of chlorogenic acid on germination and seedling growth, and on the enzymes activity extracted from Artemisia herba alba ASSO. Part I: Germination and Seedling Growth

45. Franklin G, Dias ACP (2011) Chlorogenic acid participates in the regulation of shoot, root and root hair development in Hypericum perforatum. Plant Physiol Biochem 49:835-842. https://doi.org/ 10.1016/j.plaphy.2011.05.009

46. Ulloa Rojas JB, Verreth JAJ, Amato S, Huisman EA (2003) Biological treatments affect the chemical composition of coffee pulp. Bioresour Technol 89:267-274. https://doi.org/10.1016/ S0960-8524(03)00070-1

47. Ramirez-Coronel MA, Marnet N, Kumar Kolli VS, et al (2004) Characterization and estimation of proanthocyanidins and other phenolics in coffee pulp (Coffea arabica) by Thiolysis-HighPerformance Liquid Chromatography. https://doi.org/10.1021/ JF035208T

48. Torres-Mancera MT, Cordova-López J, Rodríguez-Serrano $\mathrm{G}$ et al (2011) Enzymatic extraction of hydroxycinnamic acids from coffee pulp. Food Technol Biotechnol 49:369-373 
49. Farah A, Donangelo CM (2006) Phenolic compounds in coffee. Braz J Plant Physiol 18:23-36. https://doi.org/10.1590/S167704202006000100003

50. Kroon PA, Williamson G (1999) Hydroxycinnamates in plants and food: current and future perspectives. J Sci Food Agric 79: 355-361

51. Rodríguez-Durán LV, Ramírez-Coronel MA, Aranda-Delgado E, Nampoothiri KM, Favela-Torres E, Aguilar CN, SaucedoCastañeda G (2014) Soluble and bound hydroxycinnamates in coffee pulp (Coffea arabica) from seven cultivars at three ripening stages. J Agric Food Chem 62:7869-7876. https://doi.org/10. $1021 / \mathrm{jf5014956}$

52. Zhou Y, Ruan Z, Zhou L, Shu X, Sun X, Mi S, Yang Y, Yin Y (2016) Chlorogenic acid ameliorates endotoxin-induced liver injury by promoting mitochondrial oxidative phosphorylation. Biochem Biophys Res Commun 469:1083-1089. https://doi.org/ 10.1016/J.BBRC.2015.12.094

53. Mikami Y, Yamazawa T (2015) Chlorogenic acid, a polyphenol in coffee, protects neurons against glutamate neurotoxicity. Life Sci 139:69-74. https://doi.org/10.1016/J.LFS.2015.08.005

54. Baeza G, Amigo-Benavent M, Sarriá B, Goya L, Mateos R, Bravo L (2014) Green coffee hydroxycinnamic acids but not caffeine protect human HepG2 cells against oxidative stress. Food Res Int 62:1038-1046. https://doi.org/10.1016/J.FOODRES.2014.05. 035

55. Huang MT, Smart RC, Wong CQ, Conney AH (1988) Inhibitory effect of curcumin, chlorogenic acid, caffeic acid, and ferulic acid on tumor promotion in mouse skin by 12-O-tetradecanoylphorbol13-acetate. Cancer Res 48:5941-5946

56. Jiang Y, Kusama K, Satoh K, Takayama F, Watanabe S, Sakagami H (2000) Induction of cytotoxicity by chlorogenic acid in human oral tumor cell lines. Phytomedicine 7:483-491. https:// doi.org/10.1016/S0944-7113(00)80034-3

57. Sato Y, Itagaki S, Kurokawa T, Ogura J, Kobayashi M, Hirano T, Sugawara M, Iseki K (2011) In vitro and in vivo antioxidant properties of chlorogenic acid and caffeic acid. Int J Pharm 403:136138. https://doi.org/10.1016/J.IJPHARM.2010.09.035

58. Cho A-S, Jeon S-M, Kim M-J, Yeo J, Seo KI, Choi MS, Lee MK (2010) Chlorogenic acid exhibits anti-obesity property and improves lipid metabolism in high-fat diet-induced-obese mice. Food Chem Toxicol 48:937-943. https://doi.org/10.1016/J.FCT. 2010.01.003

59. Yun N, Kang J-W, Lee S-M (2012) Protective effects of chlorogenic acid against ischemia/reperfusion injury in rat liver: molecular evidence of its antioxidant and anti-inflammatory properties. J Nutr Biochem 23:1249-1255. https://doi.org/10.1016/J. JNUTBIO.2011.06.018

60. dos Santos MD, Almeida MC, Lopes NP, de Souza GEP (2006) Evaluation of the anti-inflammatory, analgesic and antipyretic activities of the natural polyphenol chlorogenic acid. Biol Pharm Bull 29:2236-2240. https://doi.org/10.1248/bpb.29.2236

61. Ramirez-Martinez JR (1988) Phenolic compounds in coffee pulp: quantitative determination by HPLC. J Sci Food Agric 43:135144. https://doi.org/10.1002/jsfa.2740430204

62. Suárez-Quiroz ML, Alonso Campos A, Valerio Alfaro G, González-Ríos O, Villeneuve P, Figueroa-Espinoza MC (2014) Isolation of green coffee chlorogenic acids using activated carbon. J Food Compos Anal 33:55-58. https://doi.org/10.1016/J.JFCA. 2013.10.005

63. Norata GD, Marchesi P, Passamonti S, Pirillo A, Violi F, Catapano AL (2007) Anti-inflammatory and anti-atherogenic effects of cathechin, caffeic acid and trans-resveratrol in apolipoprotein E deficient mice. Atherosclerosis 191:265-271. https://doi. org/10.1016/J.ATHEROSCLEROSIS.2006.05.047

64. Yu RJ, Van Scott EJ (1995) Method of treating wrinkles using quinic acid or quinolactone. 12
65. Wang G-F, Shi L-P, Ren Y-D, Liu QF, Liu HF, Zhang RJ, Li Z, Zhu FH, He PL, Tang W, Tao PZ, Li C, Zhao WM, Zuo JP (2009) Anti-hepatitis B virus activity of chlorogenic acid, quinic acid and caffeic acid in vivo and in vitro. Antivir Res 83:186-190. https:/ doi.org/10.1016/J.ANTIVIRAL.2009.05.002

66. Torres-Mancera MT, Baqueiro-Peña I, Figueroa-Montero A, Rodríguez-Serrano G, González-Zamora E, Favela-Torres E, Saucedo-Castañeda G (2013) Biotransformation and improved enzymatic extraction of chlorogenic acid from coffee pulp by filamentous fungi. Biotechnol Prog 29:337-345. https://doi.org/ 10.1002/btpr.1696

67. Grunberger D, Banerjee R, Eisinger K, Oltz EM, Efros L, Caldwell M, Estevez V, Nakanishi K (1988) Preferential cytotoxicity on tumor cells by caffeic acid phenethyl ester isolated from propolis. Experientia 44:230-232

68. Xiang D, Wang D, He Y, Xie J, Zhong Z, Li Z, Xie J (2006) Caffeic acid phenethyl ester induces growth arrest and apoptosis of colon cancer cells via the $\beta$-catenin/T-cell factor signaling. Anti-Cancer Drugs 17:753-762. https://doi.org/10.1097/01.cad. 0000224441.01082.bb

69. Wu J, Omene C, Karkoszka J, Bosland M, Eckard J, Klein CB, Frenkel K (2011) Caffeic acid phenethyl ester (CAPE), derived from a honeybee product propolis, exhibits a diversity of antitumor effects in pre-clinical models of human breast cancer. Cancer Lett 308:43-53. https://doi.org/10.1016/J.CANLET. 2011.04.012

70. vom Stein T, Grande PM, Kayser H et al (2011) From biomass to feedstock: one-step fractionation of lignocellulose components by the selective organic acid-catalyzed depolymerization of hemicellulose in a biphasic system. Green Chem 13:1772. https://doi.org/ $10.1039 / \mathrm{c} 1 \mathrm{gc} 00002 \mathrm{k}$

71. Grande PM, Viell J, Theyssen N, Marquardt W, Domínguez de María P, Leitner W (2015) Fractionation of lignocellulosic biomass using the OrganoCat process. Green Chem 17:3533-3539. https://doi.org/10.1039/C4GC02534B

72. Navia P. DP, Velasco M. RJ, Hoyos C. JL (2011) Production and evaluation of ethanol from coffee processing by-products. Vitae, Rev la Fac Química Farm 18:287-294

73. Orrego D, Zapata-Zapata AD, Kim D (2018) Ethanol production from coffee mucilage fermentation by $S$. cerevisiae immobilized in calcium-alginate beads. Bioresour Technol Rep 3:200-204. https://doi.org/10.1016/J.BITEB.2018.08.006

74. Reichembach LH, de Oliveira Petkowicz CL (2020) Extraction and characterization of a pectin from coffee (Coffea arabica L.) pulp with gelling properties. Carbohydr Polym 245:116473. https://doi.org/10.1016/j.carbpol.2020.116473

75. Kurniawati N, Meryandini A, Sunarti T (2016) Introduction of actinomycetes starter on coffee fruits fermentation to enhance quality of coffee pulp. Emirates J Food Agric 28:188. https://doi. org/10.9755/ejfa.2015-05-192

76. Salmones D, Mata G, Waliszewski KN (2005) Comparative culturing of Pleurotus spp. on coffee pulp and wheat straw: biomass production and substrate biodegradation. Bioresour Technol 96: 537-544. https://doi.org/10.1016/J.BIORTECH.2004.06.019

77. Coto Chinchilla O (2013) Prácticas actuales de tratamiento y disposición de los residuos agrícolas orgánicos en Costa Rica. San José, Costa Rica

78. Zeven AC (1972) The partial and complete domestication of the oil palm (Elaeis guineensis). Econ Bot 26:274-279. https://doi. org/10.1007/BF02861041

79. Obahiagbon FI (2012) A review, aspects of the African oil palm (Elaeis guineesis jacq.) and the implications of its bioactives in human health. Am J Biochem Mol Biol 106-119

80. Corley RHV, Lee CH (1992) The physiological basis for genetic improvement of oil palm in Malaysia. Euphytica 60:179-184. https://doi.org/10.1007/BF00039396 
81. Sundram K, Sambanthamurthi R, Tan YA (2003) Palm fruit chemistry and nutrition. Asia Pac J Clin Nutr 12:355-362. https://doi.org/10.1155/2015/817127

82. Hamm W, Hamilton RJ, Desmet GC (2013) Edible Oil Processing

83. STATISTA (2018) Production volume of palm oil worldwide from 2012/13 to 2017/18 (in million metric tons). In: STATISTA

84. Yeo JYJ, How BS, Teng SY, Leong WD, Ng WPQ, Lim CH, Ngan SL, Sunarso J, Lam HL (2020) Synthesis of sustainable circular economy in palm oil industry using graph-theoretic method. Sustain 12:1-29. https://doi.org/10.3390/su12198081

85. Nachtergaele P, Thybaut J, De Meester S et al (2020) Multivariate analysis of industrial biorefinery processes: strategy for improved process understanding with case studies in fatty acid production. Ind Eng Chem Res 59:7732-7745. https://doi.org/10.1021/acs. iecr.0c00515

86. Mohd Yusof SJH, Roslan AM, Ibrahim KN et al (2019) Life cycle assessment for bioethanol production from oil palm frond juice in an oil palm based biorefinery. Sustain 11:6928. https://doi.org/10. 3390/SU11246928

87. Abdul-Hamid AQ, Ali MH, Tseng ML, Lan S, Kumar M (2020) Impeding challenges on industry 4.0 in circular economy: palm oil industry in Malaysia. Comput Oper Res 123:105052. https://doi. org/10.1016/j.cor.2020.105052

88. Ocampo Batlle EA, Castillo Santiago Y, Venturini OJ, Escobar Palacio JC, Silva Lora EE, Yepes Maya DM, Albis Arrieta AR (2020) Thermodynamic and environmental assessment of different scenarios for the insertion of pyrolysis technology in palm oil biorefineries. J Clean Prod 250:119544. https://doi.org/10.1016/j. jclepro.2019.119544

89. Harahap F, Silveira S, Khatiwada D (2019) Cost competitiveness of palm oil biodiesel production in Indonesia. Energy 170:62-72. https://doi.org/10.1016/j.energy.2018.12.115

90. Mba OI, Dumont MJ, Ngadi M (2015) Palm oil: processing, characterization and utilization in the food industry - a review. Food Biosci 10:26-41. https://doi.org/10.1016/j.fbio.2015.01.003

91. Norulaini NAN, Zaidul ISM, Anuar O, Mohd. Omar AK (2004) Supercritical enhancement for separation of lauric acid and oleic acid in palm kernel oil (PKO). Sep Purif Technol 39:133-138. https://doi.org/10.1016/S1383-5866(03)00129-1

92. Sambanthamurthi R, Sundram K, Tan YA (2000) Chemistry and biochemistry of palm oil

93. Koushki M, Nahidi M, Cheraghali F (2015) Physico-chemical properties, fatty acid profile and nutrition in palm oil. J Paramed Sci 6:117-134. https://doi.org/10.22037/jps.v6i3.9772

94. Tan CH, Ghazali HM, Kuntom A, Tan CP, Ariffin AA (2009) Extraction and physicochemical properties of low free fatty acid crude palm oil. Food Chem 113:645-650. https://doi.org/10.1016/ j.foodchem.2008.07.052

95. Choo Y, Yap S, Ooi C et al (1996) Recovered oil from palmpressed fiber : a good source of natural carotenoids, vitamin E, and sterols. J Am Oil Chem Soc 73:599-602. https://doi.org/10. 1007/BF02518114

96. Macaire WH, Bernard T, Noel T et al (2010) Extraction of palm kernel oil in Cameroon: effects of kernel drying on the oil quality. J Food Technol 8:1-7. https://doi.org/10.3923/jftech.2010.1.7

97. Lange W (1994) Chemical composition of oil palm trunk extractives

98. Manurung H, Silalahi J, Siahaan D, Juliani E (2017) The reextraction of oil from oil palm empty fruit brunch residues and oil palm mesocarp fibers and measures in reducing greenhouse gas emission. Asian J Agric Biol 5:346-355

99. Yunos NSHM, Baharuddin AS, Md Yunos KF et al (2015) The physicochemical characteristics of residual oil and fibers from oil palm empty fruit bunches. BioResources 10:14-29. https://doi. org/10.15376/biores.10.1.14-29
100. Putri Primandari SR, Yaakob Z, Mohammad M, Mohamad AB (2013) Characteristics of residual oil extracted from palm oil mill effluent (POME). World Appl Sci J 27:1482-1484. https://doi. org/10.5829/idosi.wasj.2013.27.11.1422

101. Tay B, Ping Y, Yusof M (2009) Characteristics and properties of fatty acid distillates from palm oil. Oil Palm Bull 59(59):5-11. https://doi.org/10.1016/j.icheatmasstransfer.2006.02.012

102. Tan CP, Man YBC (2000) Differential scanning calorimetric analysis of edible oils: comparison of thermal properties and chemical composition. J Am Oil Chem Soc 77:143-155. https://doi.org/10. 1007/s11746-000-0024-6

103. Choe E, Min DB (2007) Chemistry of deep-fat frying oils. J Food Sci 72:R77-R86. https://doi.org/10.1111/j.1750-3841.2007. 00352.x

104. O'Brien RD (2010) Fats and oils: formulating and processing for applications, 3rd ed. CRC Press, London

105. Tan CP, Nehdi IA (2012) The physicochemical properties of palm oil and its components. In: Lai OM, Tan CP, Akoh CC (eds) Palm oil: production, processing, characterization and uses. AOCS Press, Illinois, pp 377-390

106. Abdullah N, Sulaim F (2013) The oil palm wastes in Malaysia. Biomass now - sustain growth use. https://doi.org/10.5772/55302

107. Nazir MS, Wahjoedi BA, Yussof AW, Abdullah MA (2013) Ecofriendly extraction and characterization of cellulose from oil palm empty fruit bunches. BioResources 8:2161-2172. https://oi.org/ 10.15376/biores.8.2.2161-2172

108. Ofori-Boateng C, Lee KT (2013) Sustainable utilization of oil palm wastes for bioactive phytochemicals for the benefit of the oil palm and nutraceutical industries. Phytochem Rev 12:173190. https://doi.org/10.1007/s11101-013-9270-z

109. Awalludin MF, Sulaiman O, Hashim R, Nadhari WNAW (2015) An overview of the oil palm industry in Malaysia and its waste utilization through thermochemical conversion, specifically via liquefaction. Renew Sust Energ Rev 50:1469-1484

110. Sulaiman F, Abdullah N, Gerhauser H, Shariff A (2011) An outlook of Malaysian energy, oil palm industry and its utilization of wastes as useful resources. Biomass Bioenergy 35:3775-3786. https://doi.org/10.1016/j.biombioe.2011.06.018

111. Noorshamsiana AW, Nur Eliyanti AO, Fatiha I, Astimar AA (2017) A review on extraction processes of lignocellulosic chemicals from oil palm biomass. J Oil Palm Res 29:512-527. https://doi.org/10.21894/jopr.2017.00016

112. Zahari MW, Hassan OA, Wong HK, Liang JB (2003) Utilization of oil palm frond - based diets for beef and dairy production in Malaysia. Asian-Australasian J Anim Sci 16:625-634. https://doi. org/10.5713/ajas.2003.625

113. Industry EAA for (1997) Environmental management guideline for the palm oil industry. Palm Oil Dev 30:1-10

114. Deris RRR, Sulaiman MR, Darus FM, et al (2006) Pyrolysis of oil palm trunk ( opt ). In: Som MA, Veluri MVPS, Savory RM, et al (eds) Proceedings of the 20th Symposium of Malaysian Chemical Engineers (SOMChE 2006)

115. Mohammed MAA, Salmiaton A, Wan Azlina WAKG, Mohamad Amran MS (2012) Gasification of oil palm empty fruit bunches: a characterization and kinetic study. Bioresour Technol 110:628636. https://doi.org/10.1016/j.biortech.2012.01.056

116. Roslan AM, Mohd Zahari MAK, Hassan MA, Shirai Y (2014) Investigation of oil palm frond properties for use as biomaterials and biofuels. Trop Agric Dev 58:26-29. https://doi.org/10.11248/ jsta.58.26

117. Rupani PF, Singh RP, Ibrahim H, Esa N (2010) Review of current palm oil mill effluent (POME) treatment methods: vermicomposting as a sustainable practice. World Appl Sci J 10: 1190-1201. https://doi.org/10.5539/jas.v7n4p68

118. Wu TY, Mohammad AW, Jahim JM, Anuar N (2009) A holistic approach to managing palm oil mill effluent (POME): 
Biotechnological advances in the sustainable reuse of POME. Biotechnol Adv 27:40-52. https://doi.org/10.1016/j.biotechadv. 2008.08.005

119. Dalton O, Mohamed A, Aja O (2017) Status evaluation of palm oil waste management sustainability in Malaysia. OIDA Int J Sustain Dev 10:41-48

120. Dungani R, Aditiawati P, Aprilia S et al (2018) Biomaterial from oil palm waste: properties, characterization and applications. Palm Oil. https://doi.org/10.5772/intechopen.76412

121. Lee KT, Ofori-Boateng C (2013) Sustainability of biofuel production from oil palm biomass. Springer Singapore, Singapore

122. Yasim-Anuar TAT, Ariffin H, Norrrahim MNF, Hassan MA, Tsukegi T, Nishida H (2019) Sustainable one-pot process for the production of cellulose nanofiber and polyethylene / cellulose nanofiber composites. J Clean Prod 207:590-599. https://doi. org/10.1016/j.jclepro.2018.09.266

123. Charpentier Alfaro C, Méndez Arias J (2020) Enzymatic conversion of treated oil palm empty fruit bunches fiber into fermentable sugars: optimization of solid and protein loadings and surfactant effects. Biomass Convers Biorefinery 1-10. https://doi.org/10. 1007/s13399-020-00724-y

124. Mazlan D, Krishnan S, Din MFM, Tokoro C, Khalid NHA, Ibrahim IS, Takahashi H, Komori D (2020) Effect of cellulose nanocrystals extracted from oil palm empty fruit bunch as green admixture for mortar. Sci Rep 10:1-11. https://doi.org/10.1038/ s41598-020-63575-7

125. Elias MA, Hadibarata T, Sathishkumar P (2021) Modified oil palm industry solid waste as a potential adsorbent for lead removal. Environ Chem Ecotoxicol 3:1-7. https://doi.org/10.1016/j. enceco.2020.10.003

126. Lawal AA, Hassan MA, Farid MAA, Yasim-Anuar TAT, Yusoff MZM, Zakaria MR, Roslan AM, Mokhtar MN, Shirai Y (2020) Production of biochar from oil palm frond by steam pyrolysis for removal of residual contaminants in palm oil mill effluent final discharge. J Clean Prod 265:121643. https://doi.org/10.1016/j. jclepro.2020.121643

127. Kelly-Yong TL, Teong Lee K, Mohamed AR, Bhatia S (2007) Potential of hydrogen from oil palm biomass as a source of renewable energy worldwide. Energy Policy 35:5692-5701. https://doi. org/10.1016/j.enpol.2007.06.017

128. Munawar SS, Subiyanto B (2014) Characterization of biomass pellet made from solid waste oil palm industry. Procedia Environ Sci 20:336-341. https://doi.org/10.1016/j.proenv.2014. 03.042

129. Fahma F, Iwamoto S, Hori N, Iwata T, Takemura A (2010) Isolation, preparation, and characterization of nanofibers from oil palm empty-fruit-bunch (OPEFB). Cellulose 17:977-985. https://doi.org/10.1007/s10570-010-9436-4

130. Okoroigwe EC, Saffron CM (2012) Determination of bio-energy potential of palm kernel shell by physicochemical characterization. Niger J Technol 31:329-335

131. Ahmad FB, Zhang Z, Doherty WOS, O'Hara IM (2019) The outlook of the production of advanced fuels and chemicals from integrated oil palm biomass biorefinery. Renew Sust Energ Rev 109:386-411

132. Torres C, Urvina L, de Lasa H (2019) A chemical equilibrium model for biomass gasification. Application to Costa Rican coffee pulp transformation unit. Biomass Bioenergy 123:89-103. https:// doi.org/10.1016/j.biombioe.2019.01.025

133. Santos da Silveira J, Durand N, Lacour S, Belleville MP, Perez A, Loiseau G, Dornier M (2019) Solid-state fermentation as a sustainable method for coffee pulp treatment and production of an extract rich in chlorogenic acids. Food Bioprod Process 115:175184. https://doi.org/10.1016/j.fbp.2019.04.001

134. Cheng JJ (2017) Biomass to renewable energy processes
135. Anwar M (2021) Biodiesel feedstocks selection strategies based on economic, technical, and sustainable aspects. Fuel 283:119204. https://doi.org/10.1016/j.fuel.2020.119204

136. Singh SP, Singh D (2010) Biodiesel production through the use of different sources and characterization of oils and their esters as the substitute of diesel: a review. Renew Sust Energ Rev 14:200-216. https://doi.org/10.1016/j.rser.2009.07.017

137. Kuss VV, Kuss AV, Da Rosa RG et al (2015) Potential of biodiesel production from palm oil at Brazilian Amazon. Renew Sust Energ Rev 50:1013-1020. https://doi.org/10.1016/j.rser.2015.05. 055

138. Instituto Interamericano de Cooperación para la Agricultura (2007) Atlas de la Agroenergía y los Biocombustibles en las Américas II. Biodiesel. IICA

139. Ministerio de Ambiente y Energía \& Ministerio de Agricultura y Ganadería (2008) Programa Nacioal de Biocombustibles. San José

140. Thompson JC, He BB (2006) Characterization of crude glycerol from biodiesel production from multiple feedstocks. Appl Eng Agric 22:261-265. https://doi.org/10.13031/2013.20272

141. Lari GM, Pastore G, Haus M, Ding Y, Papadokonstantakis S, Mondelli C, Pérez-Ramírez J (2018) Environmental and economical perspectives of a glycerol biorefinery. Energy Environ Sci 11: 1012-1029

142. Nomanbhay S, Hussein R, Ong MY (2018) Sustainability of biodiesel production in Malaysia by production of bio-oil from crude glycerol using microwave pyrolysis: a review. Green Chem Lett Rev 11:135-157

143. Tudorache M, Negoi A, Protesescu L, Coman SM (2013) Bioglycerol as sustainable raw material for biorefinery - biocatalytic synthesis of glycerol carbonate ABSTRACT : 2-6. https://doi.org/ 10.5071/21stEUBCE2013-2DO.10.2

144. Shahbaz K, Hashim MA, AlNashef IM, Mjalli FS (2010) Using deep eutectic solvents for the removal of glycerol from palm oilbased biodiesel. J Appl Sci 10:3349-3354. https://doi.org/10. 1111/gcb.12950

145. El-Araby R, Amin A, El Morsi AK et al (2018) Study on the characteristics of palm oil-biodiesel-diesel fuel blend. Egypt J Pet 27:187-194. https://doi.org/10.1016/j.ejpe.2017.03.002

146. Wan Isahak WNR, Che Ramli ZA, Ismail M, Mohd Jahim J, Yarmo MA (2015) Recovery and purification of crude glycerol from vegetable oil transesterification. Sep Purif Rev 44:250-267. https://doi.org/10.1080/15422119.2013.851696

147. Hájek M, Skopal F (2010) Treatment of glycerol phase formed by biodiesel production. Bioresour Technol 101:3242-3245. https:// doi.org/10.1016/j.biortech.2009.12.094

148. Isahak WNRW, Ismail M, Yarmo MA, Jahim JM, Salimon J (2010) Purification of crude glycerol from transesterification rbd palm oil over homogeneous and heterogeneous catalysts for the biolubricant preparation. J Appl Sci 10:2590-2595. https://doi. org/10.3923/jas.2010.2590.2595

149. Yong K, Ooi T (2001) Refining of crude glycerine recovered from glycerol residue by simple vacuum distillation. J Oil Palm ... 13: 39-44

150. Ooi TL, Yong KC, Dzulkefly K et al (2001) Crude glycerine recovery from glycerol residue waste from a palm kernel oil methyl ester plant. J Oil Palm Res 13:16-22. https://doi.org/10.1016/j. athoracsur.2016.11.031

151. Teles Dos Santos M, Gerbaud V, LeRoux GAC (2014) Beyond biofuels: economic opportunities, recent advances and challenges in property modeling for vegetable oils. Green Process Synth 3: 401-410. https://doi.org/10.1515/gps-2014-0050

152. Demirbas A (2003) Biodiesel fuels from vegetable oils via catalytic and non-catalytic supercritical alcohol transesterifications and other methods: a survey. Energy Convers Manag 44:20932109. https://doi.org/10.1016/S0196-8904(02)00234-0 
153. Ma FF, Hanna MA (1999) Biodiesel production: a review. Bioresour Technol 70:1-15. https://doi.org/10.1016/s09608524(99)00025-5

154. Vicente G, Martínez M, Aracil J (2007) Optimisation of integrated biodiesel production. Part I. A study of the biodiesel purity and yield. Bioresour Technol 98:1724-1733. https://doi.org/10.1016/j. biortech.2006.07.024

155. Schuchardt U, Sercheli R, Vargas RM (1998) Transesterification of vegetable oils: a review. J Braz Chem Soc 9:199-210

156. Park YM, Lee DW, Kim DK, Lee JS, Lee KY (2008) The heterogeneous catalyst system for the continuous conversion of free fatty acids in used vegetable oils for the production of biodiesel. Catal Today 131:238-243. https://doi.org/10.1016/j.cattod.2007.10.052

157. López DE, Goodwin JG, Bruce DA (2007) Transesterification of triacetin with methanol on Nafion acid resins. J Catal 245:381391. https://doi.org/10.1016/j.jcat.2006.10.027

158. Arzamendi G, Campo I, Arguiñarena E, Sánchez M, Montes M, Gandía LM (2007) Synthesis of biodiesel with heterogeneous $\mathrm{NaOH} /$ alumina catalysts: comparison with homogeneous $\mathrm{NaOH}$. Chem Eng J 134:123-130. https://doi.org/10.1016/j.cej.2007.03. 049

159. Al-Zuhair S (2007) Production of biodiesel: possibilities and challenges. Biofuels Bioprod Biorefin 1:57-66
160. Abnisa F, Arami-Niya A, Daud WMAW, Sahu JN (2013) Characterization of bio-oil and bio-char from pyrolysis of palm oil wastes. Bioenergy Res 6:830-840. https://doi.org/10.1007/ s12155-013-9313-8

161. Vindas Segura M (2015) Utilizan desechos de piña, café y árboles como fuente de energía. In: Portal la Investig

162. Poh PE, Chong MF (2009) Development of anaerobic digestion methods for palm oil mill effluent (POME) treatment. Bioresour Technol 100:1-9. https://doi.org/10.1016/j.biortech.2008.06.022

163. Guillén Watson R, Rivas Solano O (2011) Producción de metano a partir de desechos orgánicos generados en el Tecnológico de Costa Rica. Tecnol en Marcha 25:74-80. https://doi.org/10. $18845 / \mathrm{tm} . v 25 \mathrm{i} 2.1631$

164. Hernández Sandí M (2017) Evaluación del perfil de carotenoides y su bioaccesibilidad in vitro en frutos de pejibaye ( Bactris gasipaes H . B . K ) de coloración amarilla y coloración roja , considerando sus características físico- químicas y el efecto de adición de grasa previo a. University of Costa Rica

Publisher's note Springer Nature remains neutral with regard to jurisdictional claims in published maps and institutional affiliations. 